\title{
Fire behavior of shallow prestressed hollow core slabs from computational modeling
}

\section{Análise do comportamento de lajes alveolares de altura reduzida em situação de incêndio via modelagem computacional}
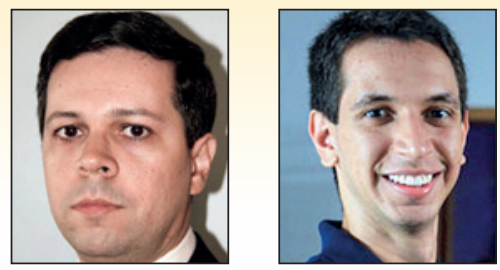

\author{
D. L. ARAÚJO \\ dlaraujo@ufg.br \\ https://orcid.org/0000-0002-6802-4637 \\ G. D. C. PINTO \\ guilhermecosta.engcivil@gmail.com \\ https://orcid.org/0000-0001-6559-7483
}

\begin{abstract}
Prestressed hollow core slabs are one of the structural systems whose use has increased the most in recent years in Brazil due to its efficiency and versatility. They can be used in many types of structural systems, such as masonry, precast concrete, cast-in-place concrete and steel structures. However, there are few analytical models to evaluate the fire behavior of hollow core slabs. In a simplified way, the fire resistance is evaluated indirectly through the minimum distance of the surface in contact with fire to the reinforcement axis. In this paper, some numerical models in finite element software were developed to analyze the variation of temperature with fire exposure time of shallow hollow core slabs, focusing on the presence of voids in the transversal section of the slab. The $500{ }^{\circ} \mathrm{C}$ isotherm method applied to $20 \mathrm{~cm}$ high slabs confirmed the Standard Fire Resistance obtained from the tabular method. However, when applied to shallow prestressed hollow core slabs that are $16 \mathrm{~cm}$ high, the $500{ }^{\circ} \mathrm{C}$ isotherm method indicated that the Standard Fire Resistance of these slabs is lower than values obtained from tabular methods.
\end{abstract}

Keywords: shallow hollow-core slabs, fire resistance, precast concrete, computational modeling.

\section{Resumo}

As lajes alveolares protendidas são um dos sistemas estruturais que mais ganhou força nos últimos anos no Brasil devido a sua eficiência e versatilidade. Podem ser empregadas em vários tipos de sistemas construtivos como: alvenaria estrutural, concreto pré-moldado, concreto moldado in loco e estrutura metálica. Contudo, ainda há poucos modelos de cálculo racionais para avaliar o comportamento ao fogo das lajes alveolares, sendo que, de forma simplificada, sua resistência ao fogo é avaliada de forma indireta pela garantia de uma distância mínima do eixo da armadura até a face do elemento estrutural submetida ao fogo. Neste artigo são apresentados alguns modelos numéricos desenvolvidos em um programa de elementos finitos para analisar a distribuição da temperatura em lajes alveolares de altura reduzida quando em situação de incêndio, com foco na influência da presença dos alvéolos. O método das isotermas de $500^{\circ} \mathrm{C}$ aplicado a lajes com $20 \mathrm{~cm}$ de altura confirmaram alguns dos Tempos Requeridos de Resistência ao Fogo (TRRF) indicados nos métodos tabulares. Contudo, quando aplicados a lajes alveolares com altura de 16 $\mathrm{cm}$, o método das isotermas de $500^{\circ} \mathrm{C}$ indicou que o TRRF dessas lajes é inferior ao indicado nos métodos tabulares.

Palavras-chave: laje alveolar, incêndio, pré-moldado, modelagem computacional.

Universidade Federal de Goiás, Goiânia, GO, Brasil. 


\section{Introduction}

In precast construction, the hollow core slab is a structural element whose use has been rapidly increased due to its versatility and agility observed in the execution and assembly of structures. This slab can be used in many types of structural systems: in situ concrete, precast concrete, masonry and even in steel structures. Although the use of hollow core slabs in Brazil has increased significantly, in Europe it is produced in a much higher scale due to the industrialization process and project optimization developed in countries such as Germany, France and England.

The hollow core slab is a widespread system and has been deeply investigated in the last years to determine its behavior in fire conditions. There are many experimental and numerical studies which analyze various situations of hollow core slabs regarding the effects of loading and support of the slabs on the rest of the structure. In Europe and United States, there are standards and handbooks for the design of structures under fire conditions, such as Eurocode 1 [1] and ASTM-E119 [2], which deal with the main definitions of fire and show standard fire curves. The Eurocode 2 [3] and the $\mathrm{ACl}-216.1-\mathrm{M}-07$ [4] standards present design methods and reduction coefficients for material strength with the elevation of the temperature. The $\mathrm{PCl}$ [5] manual and the BS EN 1168 [6] can be used to design prestressed hollow cores slabs in fire conditions.

In Brazil, the fire design of concrete structures is covered in the NBR 15200:2012 [7] and NBR 14432:2001 [8] standards. The NBR 15200:2012 [7] standard presents only a tabular method for fire design of concrete structures and does not deal in its tables with the design of hollow core slabs. The recent revision of the Brazilian standard for the design of precast concrete structures, NBR 9062:2017 [9], presents some criteria for the design of hollow core slabs in fire conditions, but this criterion is based only on the minimum values for the height of the hollow core slab and for the distance from the strand reinforcement to the face of the structural element subjected to fire.

This article aims to determine the temperature profile in shallow prestressed hollow core slabs under fire conditions by means of computational modeling in finite element software. The presence of the voids in the cross-section was also considered. The developed thermal modeling strategies are validated by comparing the results of a thermo-mechanical numerical model with test results available in the literature of hollow core slabs under fire conditions and subjected to bending. The $500{ }^{\circ} \mathrm{C}$ isotherm simplified design method is used to estimate the reduction of bending moment with time of fire exposure of a shallow hollow core slab.

It is important to deepen the knowledge about the behavior of hollow core slabs exposed to fire. There are several studies in the literature about reinforced concrete beams and columns exposed to fire [1013], as well as steel-concrete composite structures [14-17]. There are also several studies about the behavior of hollow core slabs exposed to fire, either by tests or computational modeling [18-27]. However, most of these studies consider hollow core slabs with high height. The lowest height observed in these studies was $20 \mathrm{~cm}$, and mostly with circular voids. Thus, there is still a gap of knowledge about the hollow core slabs with height smaller than $20 \mathrm{~cm}$ with noncircular voids, which are employed in buildings with small spans.

\section{Fire design methods of reinforced concrete structures}

According to Costa [28], the design of a structure under fire conditions is analyzed by the thermal and mechanical responses of the structure under a transient thermal action. When a structure is analyzed at room temperature, that is, considering only the static service loads, the procedure is simpler due to the well-known structural behavior of the elements (beams, slabs or columns) and its failure mechanisms.

Already in fire conditions, because it is an exceptional action, as well as earthquakes or explosions that introduce dynamic actions on structures, the behavior of structural elements is a hardly known. There is a great influence of the thermal properties of the materials in the way that heat is transferred to the structure. There are also the questions about how the temperature of the structure increases when it is exposed to fire and if the fire is contained in a compartment or not.

According to Costa [28], thermal analysis quantifies the heat transmission of the exposed face to the interior of the element by means of the conduction phenomenon, establishing the profile temperatures in the cross-section. In a more complete analysis, the thermal behavior of a structure is also affected by the radiation and convection phenomena. From the temperature profile of the cross-section, it is possible to determine the mechanical strength of the materials, that is, steel and concrete, at elevated temperatures. When a previous temperature profile is gradually applied to a structural element submitted to mechanical loading, a thermomechanical response is obtained.

An adequate fire design of the concrete structure is obtained when the following requirements are fulfilled: the connections between structural elements support thermal actions and the heat cannot propagate rapidly along the structure, which prevent failure of other structural elements which are not directly exposed to fire.

When a structure is designed for fire resistance, it implies that the structure, or a part of the structure or a member fulfills its required functions (load bearing function and/or fire separating function) for a specified load level, for a specified fire exposure and for a specified period of time. The designer must ensure that the structure satisfies the fire-resistance class established in standards for each type of element [29]. In Brazil, the NBR 14432:2001 standard [8] defines the desired fire resistance time (TRRF) as the fire resistance of a structural element when exposed to heating according to the standard temperature-time curve. According to Silva [30], the TRRF does not mean the duration of a fire, or time for dispatch or response of the fire brigade, but rather a design parameter. In other words, the TRRF is an equivalent time of fire exposure, that is, the time of exposure to the standard temperature-time curve that is supposed to have the same heating effect as a real fire in the compartment.

\subsection{Tabular method}

The tabular methods are the simplest, most traditional and are currently used by designers. Because it is a simple way to determine the fire resistance, these methods involve several restrictions and 
are very safe. For non-tabulated data, interpolations are required to reach the fire resistance. Application of the tabular method is restricted to usual elements with predefined geometry contained in tables. The tabular method is based on the principle that the fire resistance of the element increases with the increase of the distance between axis of the reinforcement and the face of concrete exposed to fire due to the reduction of the temperature in the reinforcement. Temperatures tend to decrease in the center of the concrete crosssection due to its low conductivity. Therefore, if the thickness of the element and the distance from the axis of the reinforcement to the face exposed to heat increase, more time will elapse until the structural element reaches failure under mechanical loading. In the tabular method, no further check is required for bending, shear or torsion capacity and anchorage details, and the explosive spalling of concrete is not checked.

The Brazilian standard NBR 15200:2012 [7] is based on tabulated data presented in Eurocode 2 [3]. The minimum values of the thicknesses of the structural elements and the axis distance of the reinforcement to the face exposed to fire depend on the structural element type and the TRRF, which is a function of the construction type (residential, commercial, industrial, educational, etc.). Table 1 shows the minimum thickness and axis distance $\left(c_{1}\right)$ for solid, simply supported, reinforced concrete slabs for standard fire resistance according to NBR 15200:2012 [7].

Tabulated data are based on a reference load level for fire design equal to $70 \%$ of the load level for ambient temperature. Therefore, the values shown in tables can be reduced for elements where the load level for fire design is less than $70 \%$ of the load level for ambient temperature. Table 2 shows the minimum dimensions for simply supported ribbed slabs, according to Brazilian standard NBR 15200:2012 [7]. The values of $c_{1}$ in Tables 1 and 2 are valid for reinforced concrete and $15 \mathrm{~mm}$ must be added for prestressed concrete.
The latest version of Brazilian standard NBR 9062:2017 [9] shows some recommendations for fire design of hollow core slabs by tabulated data. The minimum axis distance for bending capacity $\left(\mathrm{c}_{1}\right)$ is expressed as a ratio of factored design moment in fire conditions $\left(\mathrm{M}_{\mathrm{Sd}}\right)$ and the design moment capacity $\left(\mathrm{M}_{\mathrm{Rd}}\right)$ at ambient temperature. Table 3 shows some combinations between slab thickness $(h)$ and minimum axis distance $\left(c_{1}\right)$ for each ratio of $M_{\mathrm{Sd}} / M_{R d}$. The slab thickness presented in Table 3 can be considered as the sum of the thickness of the hollow core slab and the thickness of the cast-inplace concrete topping. Moreover, these values are true for hollow core slabs with a void index (ratio between the average thickness and the height of the slab) greater than or equal to 0.5 .

\section{$2.2500{ }^{\circ} \mathrm{C}$ isotherm method}

This method was developed in Sweden and is one of the best known to designers. The simplified calculation method comprises a general reduction of the cross-section size with respect to a heat damaged zone at the concrete surface. The thickness of the damaged concrete is made equal to the average depth of the $500{ }^{\circ} \mathrm{C}$ isotherm in the compression zone of the cross-section. Moreover, damage concrete, that is, concrete with temperature in excess $500{ }^{\circ} \mathrm{C}$, is assumed not to contribute to the load bearing capacity of the element. The residual concrete cross-section retains its initial values of strength and modulus of elasticity. Reinforcement steel in zones with a temperature greater than $500{ }^{\circ} \mathrm{C}$ is not excluded in the analysis, but its mechanical strength is reduced due to the temperature [21]. Tests carried out with varied mechanical loading and desired fire resistance time (TRRF) confirmed that the simplification of excluding the cross-section for that with temperature greater than $500^{\circ} \mathrm{C}$ is valid for normal density concretes and siliceous aggregates [28]. According to Klein Júnior [29], the $500{ }^{\circ} \mathrm{C}$ isotherm method can be

\section{Table 1}

Minimum thickness $(h)$ and axis distance from the reinforcement to the face exposed to fire $\left(c_{1}\right)$ for simply supported slabs [7]

\begin{tabular}{|c|c|c|c|c|}
\hline \multirow{2}{*}{$\begin{array}{l}\text { TRRF } \\
\text { (min) }\end{array}$} & \multirow{2}{*}{$\begin{array}{c}\mathrm{h} \\
(\mathrm{mm})\end{array}$} & \multicolumn{3}{|c|}{$c_{1}(\mathrm{~mm})$} \\
\hline & & $\begin{array}{c}\text { Two-way reinforced slab } \\
\ell_{\mathrm{x}} / \ell_{\mathrm{y}} \leq 1.5\end{array}$ & $\begin{array}{c}\text { Two-way reinforced slab } \\
1.5 \leq \ell_{x} / \ell_{y} \leq 2.0\end{array}$ & $\begin{array}{c}\text { One-way reinforced slab } \\
\ell_{\mathrm{x}} / \ell_{\mathrm{y}} \geq 2.0\end{array}$ \\
\hline 30 & 60 & 10 & 10 & 10 \\
\hline 60 & 80 & 10 & 15 & 20 \\
\hline 90 & 100 & 15 & 20 & 30 \\
\hline 120 & 120 & 20 & 25 & 40 \\
\hline 180 & 150 & 30 & 40 & 55 \\
\hline
\end{tabular}

\section{Table 2}

Minimum dimensions for simply supported ribbed slabs in a fire [7]

\begin{tabular}{ccccc}
\hline TRRF & \multicolumn{2}{c}{ Ribbed: combinations of $\mathbf{b}_{\min } / \mathbf{c}_{\mathbf{1}}(\mathbf{m m} / \mathbf{m m})^{1}$} & $\mathbf{3}$ & $\begin{array}{c}\text { Concrete topping: } \\
\mathbf{h} / \mathbf{c}_{1}(\mathbf{m m} / \mathbf{m m})^{2}\end{array}$ \\
\cline { 2 - 4 }$(\mathrm{min})$ & $\mathbf{1}$ & $\mathbf{2}$ & - & $60 / 10$ \\
60 & $80 / 15$ & - & $190 / 15$ & $80 / 10$ \\
90 & $100 / 35$ & $120 / 25$ & $250 / 30$ & $100 / 15$ \\
120 & $120 / 45$ & $160 / 40$ & $300 / 40$ & $120 / 20$ \\
180 & $160 / 60$ & $190 / 55$ & $410 / 60$ & $150 / 30$ \\
\hline
\end{tabular}


Table 3

Minimum slab thickness and axis distance for simply supported hollow core floors [9]

\begin{tabular}{|c|c|c|c|c|}
\hline \multirow{3}{*}{$\begin{array}{l}\text { TRRF } \\
(\mathrm{min})\end{array}$} & \multicolumn{4}{|c|}{$\begin{array}{l}\text { Minimum slab thickness (with or without concrete topping) / minimum axis distance } \mathrm{c}_{1} \\
\mathrm{~mm} / \mathrm{mm}\end{array}$} \\
\hline & $M_{s d} / M_{r d}(\%)$ & $\mathrm{M}_{\mathrm{sd}} / \mathrm{M}_{\mathrm{rd}}(\%)$ & $M_{s d} / M_{r d}(\%)$ & $\mathrm{M}_{\mathrm{sd}} / \mathrm{M}_{\mathrm{rd}}(\%)$ \\
\hline & $30-39$ & $40-49$ & $50-59$ & $>60$ \\
\hline 30 & - & - & - & All slabs /30 \\
\hline 60 & - & - & - & $150 / 30$ \\
\hline 90 & - & $\begin{array}{l}200 / 35 \\
265 / 35 \\
320 / 35 \\
400 / 35\end{array}$ & $\begin{array}{l}200 / 40 \\
265 / 40 \\
320 / 40 \\
400 / 40\end{array}$ & $200 / 40$ \\
\hline 120 & - & $\begin{array}{l}200 / 40 \\
265 / 40 \\
320 / 40 \\
400 / 40\end{array}$ & - & $200 / 50$ \\
\hline 180 & $\begin{array}{l}200 / 50 \\
265 / 50 \\
320 / 50 \\
400 / 50\end{array}$ & $200 / 60$ & $\begin{array}{l}265 / 60 \\
320 / 60 \\
400 / 60\end{array}$ & - \\
\hline
\end{tabular}

applied to any fire curve, since the cross-section data (height, width and position of the reinforcement) and the temperature profile are known. This simplified calculation method can be used for structural elements subjected to simple bending or composite bending. The basic procedures for this calculation method are: determine the temperature profile in the cross-section of the structure for a specific value of TRRF, reduce the cross-section, excluding the concrete outside the $500{ }^{\circ} \mathrm{C}$ isotherm, determine the temperature of reinforcing bars in the tension and compression zone, determine the reduced strength of the steel reinforcement due to temperature, determine the ultimate load bearing capacity with the strength of the reinforcing bars using the conventional calculation method for the reduced cross-section. Finally, the estimated fire resistance should be compared with the fire design loading.

\section{Computational modeling}

DIANA $^{\circledast} 9.6$ [31] is a finite element software package that can be applied to simulate typical structures of civil engineering and others engineering sciences (mechanical, biomechanics, etc.). For thermo-mechanical analysis, the DIANA ${ }^{\circledR} 9.6$ [31] software has a specific module to process the structures. This is the junction of the nonlinear structural module with the heat flow analysis. Each module has its own finite element library, set of loadings and constitutive law of materials.

According Rocha [32], all data should be considered in only one model, because the DIANA ${ }^{\circledR}$ software will automatically convert the results of thermal analysis into data for structural analysis in coupled thermo-mechanical analyses. The thermal model must consist of elements with linear interpolation, while in the structural model the elements can have quadratic interpolation, the software being responsibility for the compatibilization of the elements.

\subsection{Constitutive law of materials}

A constitutive law of materials to represent the mechanical behavior of materials at ambient temperature should be defined, and the variation of these properties with temperature should also be defined. In this paper, the reduction of the mechanical properties of concrete and steel with temperature is given in Figure 1, which is similar to that recommended in Eurocode 2 [3]. The steel was considered a perfect elastoplastic material with von Mises yield criterion, both at ambient temperature and at elevated temperature.

The DIANA ${ }^{\circledR} 9.6$ software [31] does not have a multilinear stressstrain relationship for compressive and tensile strength of concrete at elevated temperature, as shown in Eurocode 2 for concrete under compression. Therefore, the Total Strain Crack Model with smeared cracking was used to represent the mechanical behavior of the concrete. In this model, the DIANA ${ }^{\circledast} 9.6$ software [31] represents the mechanical behavior of concrete by a predefined uniaxial stress-strain relationship, which depends only on the modulus of elasticity and uniaxial strength. In this paper, the exponential tension softening model shown in Figure 2a for concrete under tension and the parabolic model shown in Figure $2 b$ for concrete under compression were adopted. The Mode-I fracture energy $\left(G_{F}\right)$, as well as its variation with the temperature, was adopted from research of Rocha [32] and Santos [33], shown in Figure 1, which presented good results when compared to experimental results of steel-concrete composite beams. The compressive fracture energy $\left(G_{C}\right)$, in all analyses, was taken equal to one hundred times the Mode-I fracture energy [34]. Thus, the compressive fracture energy and the uniaxial stress-strain relationship of concrete under compression varied with the temperature according to the variation adopted for the Mode-I fracture energy.

\subsection{Finite element mesh}

Two types of finite elements are required to perform a heat flow analysis in DIANA ${ }^{\circledR} 9.6$ software [31]: one to represent the volume of the structural element and another for the regions where the thermal loads are applied, also called boundary conditions. The Q4HT finite element for heat flow analysis of hollow core slabs in two dimensions was used. It is a four-node quadrilateral isoparametric element for general potential flow analysis, shown 
in Figure 3. It is based on linear interpolation and Gauss integration. For boundary conditions, the B2HT element was used. It is a two-node isoparametric straight boundary element for general potential flow analysis. It is also based on linear interpolation and Gauss integration, shown in Figure 4.

For three-dimensional thermo-mechanical analyses of the hollow

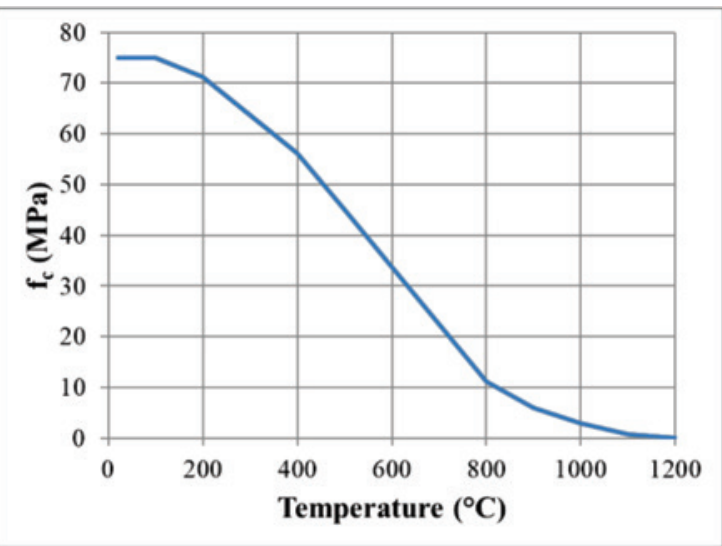

(a)

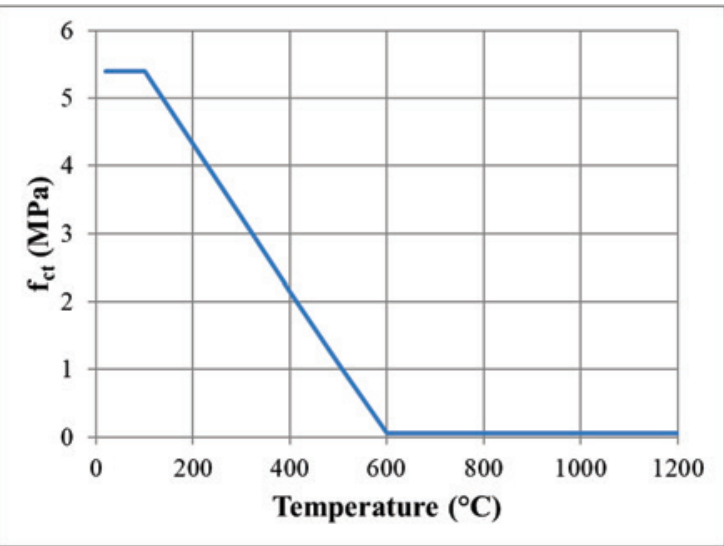

(c)

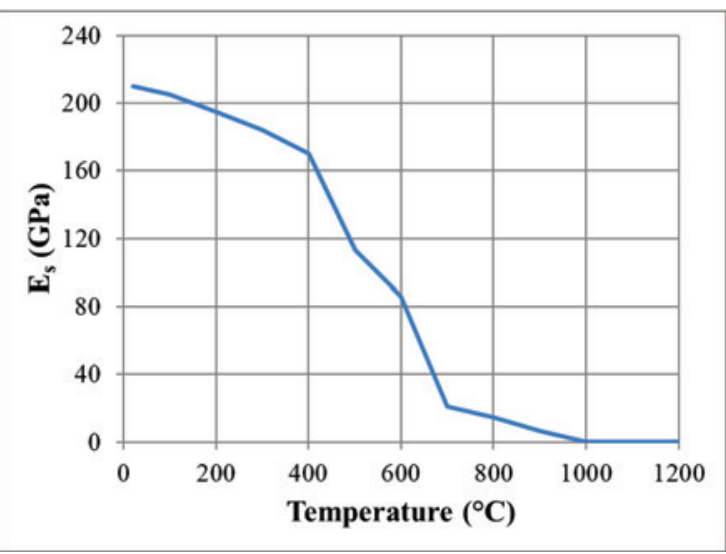

(e)

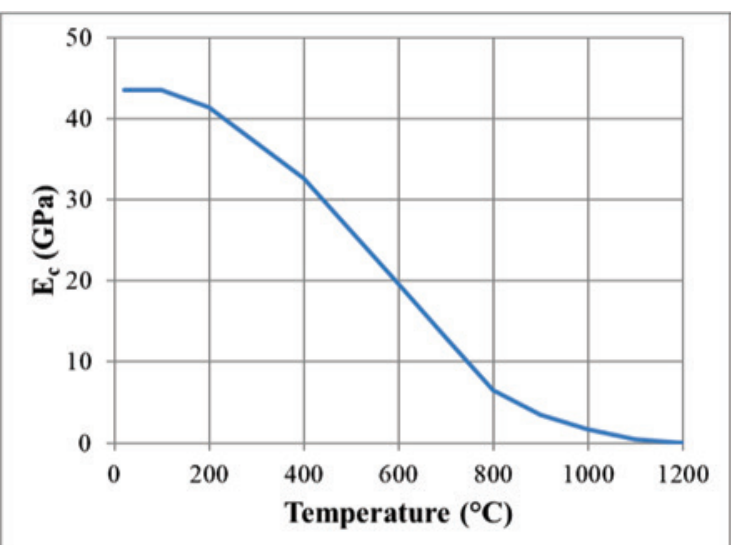

(b)

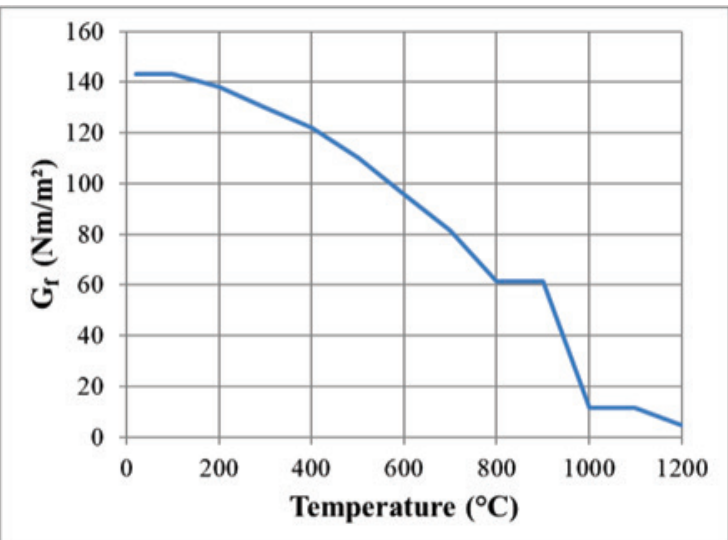

(d)

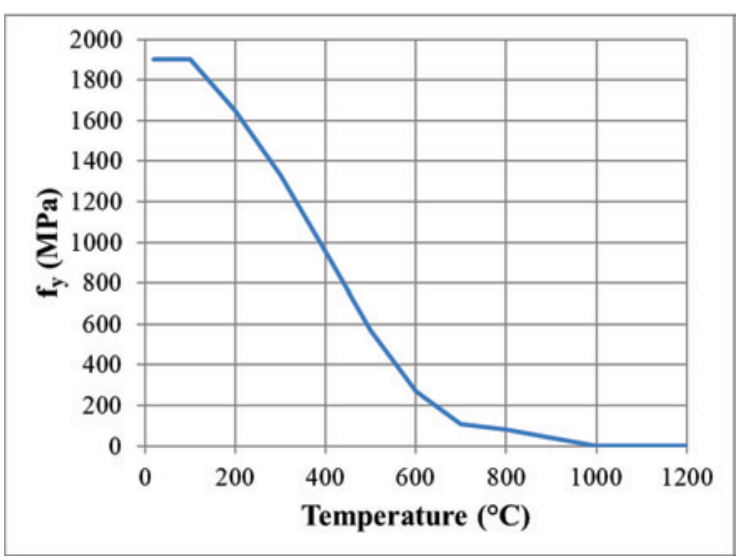

(f)

\section{Figure 1}

Reduction of mechanical properties of concrete and steel with temperature: (a) compressive strength of the concrete (siliceous aggregate), (b) modulus of elasticity of concrete, (c) concrete tensile strength, (d) Mode-l fracture energy of concrete, (e) modulus of elasticity of steel, $(f)$ yield strength of prestressing steel 


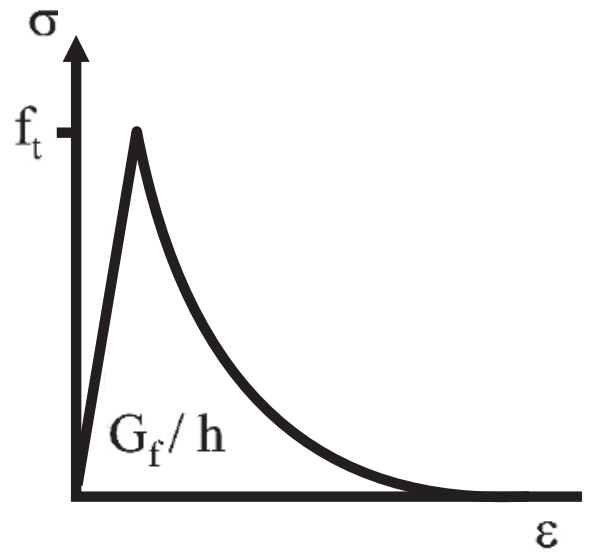

(a)

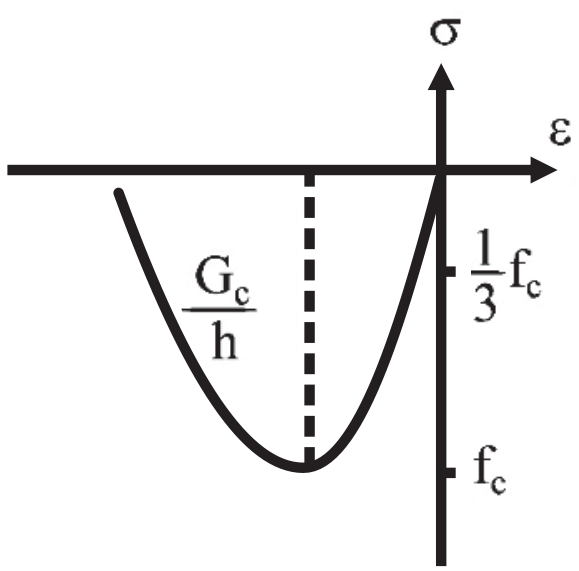

(b)

Figure 2

Predefined uniaxial behavior for total strain model [31]: (a) tension softening; (b) compression

core slab, the $\mathrm{CHX60}$ finite element was used. It is a twenty-node isoparametric solid brick element and is based on quadratic interpolation and Gauss integration (Figure 5). For boundary conditions, the BQ4HT finite element was used. It is a four-node isoparametric quadrilateral element to describe boundaries in three-dimensional

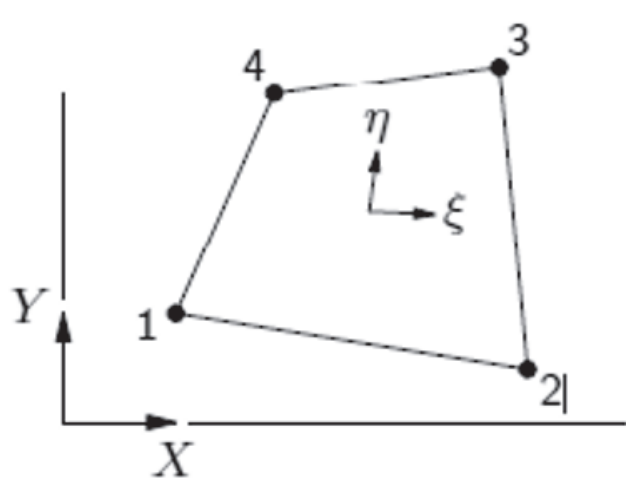

Figure 3

Finite element Q4HT [31]

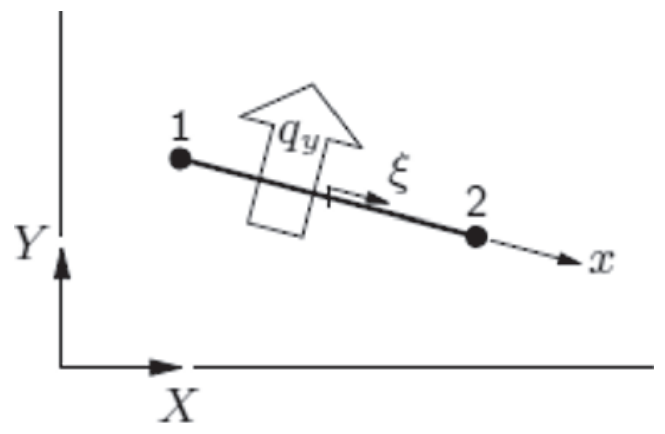

Figure 4

Finite element B2HT [31] general potential flow analysis (Figure 6). It is based on linear interpolation and Gauss integration.

In this thermo-mechanical analysis, the selected boundary

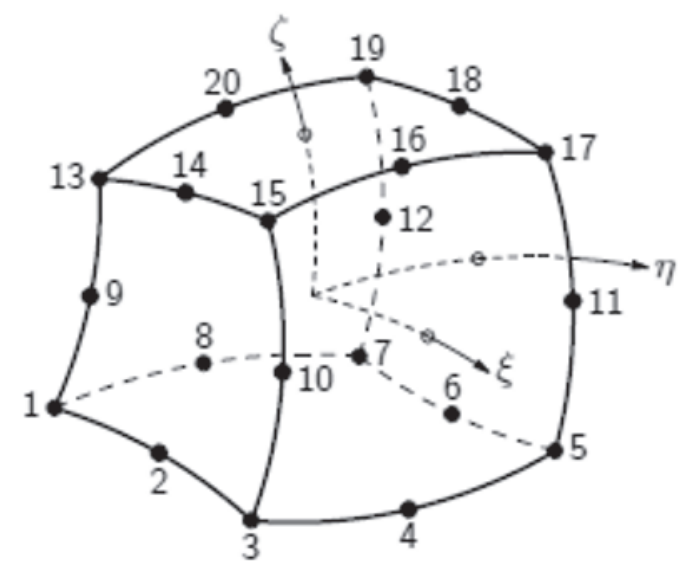

Figure 5

Finite element CHX60 [31]

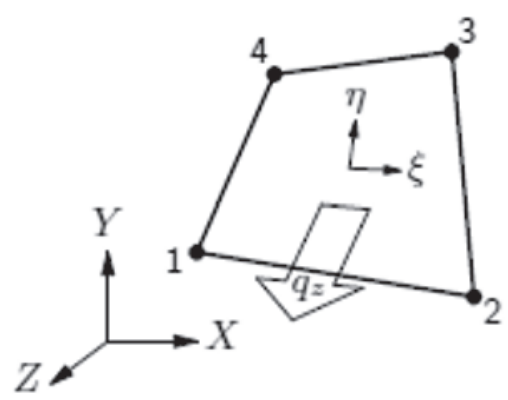

Figure 6

Finite element BQ4HT [31] 
condition is based on linear interpolation and it is incompatible with the $\mathrm{CHX60}$ finite element. The DIANA ${ }^{\circledR} 9.6$ software automatically makes the compatibilization of the $\mathrm{CHX60}$ structural element with the BQ4HT finite element [31]. The temperature on the faces of hollow core slab not exposed to fire was defined as $20^{\circ} \mathrm{C}$.

The prestressing strands were modeled by embedding reinforcement elements, which simulate the perfect bond of bar reinforcement and concrete. The prestress load in the model was applied as initial loading condition.

\subsection{Boundary conditions and loading}

Two models were developed, i.e., a two-dimensional heat flow analysis and a three-dimensional thermo-mechanical analysis. Convection at boundaries of the continuum model and radiation were considered in models developed in DIANA ${ }^{\circledR} 9.6$ [31]. The concentrated mechanical loading in the thermo-mechanical model was applied as pressure on the region of load applied.

Boundary elements in heat flow analysis are placed on faces to simulate the heat conduction between the structure and the ambient air. For a hollow core slab, the bottom surface is exposed to fire. The top face and side faces are insulated and do not transfer heat to ambient air. Inside the voids, there is heat flow from its lower (hotter) area to the upper (colder) area through convection and radiation flux of the air inside the voids. Thus, the heat flow along the cross-section of the slab takes into ac- count conduction, as well as the convection and radiation inside the voids.

The thermo-mechanical analysis is performed in three steps. In the first step, the initial stress state due to the prestressing strands is imported as the initial condition. This stress state due prestressing is constant over all the analysis, i.e., it is assumed that there is no prestressing loss due to elevated temperature and all stress loss occurs before exposing the slab to fire. The second step consists in applying the mechanical loading, as percentage of the maximum load capacity of the ambient temperature. This loading is applied incrementally by performing a physical nonlinear analysis and is maintained constant during thermal analysis. Thirdly, the temperature profile is imported from the thermal model, and a transient analysis is evaluated. The time-dependent profile induces thermal strain and degradation of material properties. The calculation is stopped when the hollow core slab is so damaged that convergence cannot be achieved. This methodology is similar to previous research developed and reported in the technical literature [20].

\section{Validation of the computational model}

Throughout this section, both the heat flow and the thermo-mechanical models developed in DIANA ${ }^{\circledR}$ are validates using a previous experimental result obtained by Shakya and Kodur [26] for hollow core slabs exposed to standard fire according to ASTM-E119.

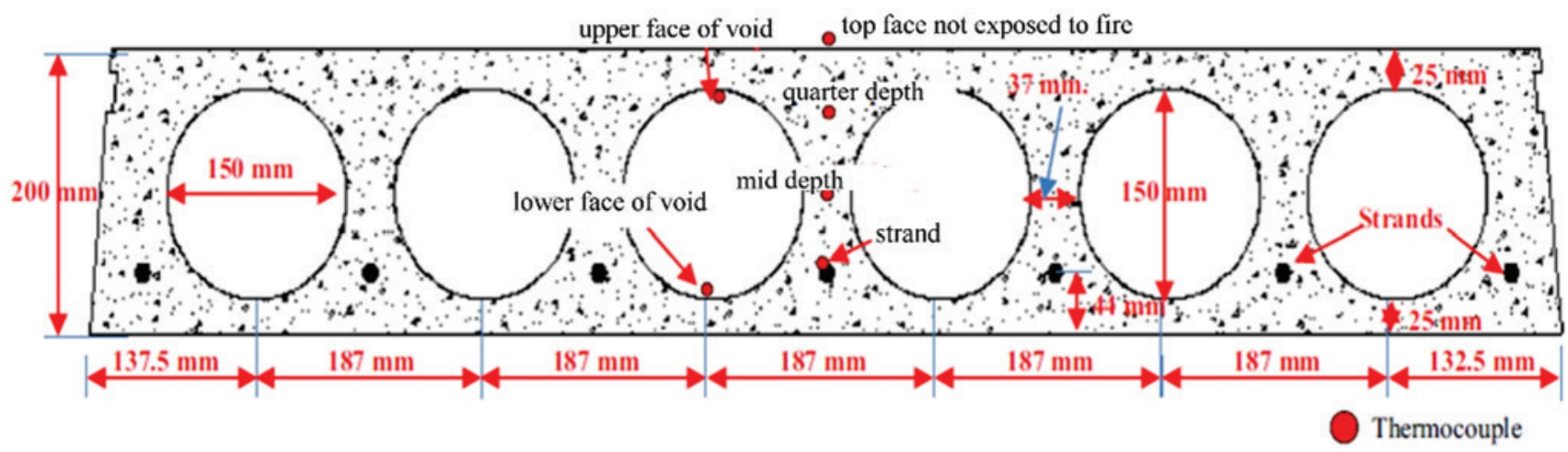

\section{Figure 7}

Cross-section of hollow core slab used in validation of the computational model [26]

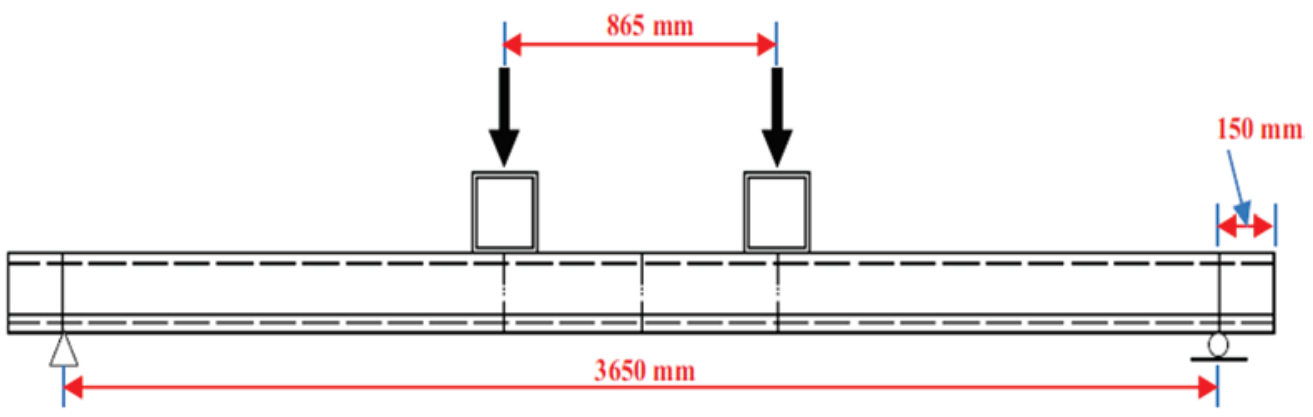

\section{Figure 8}

Test setup of hollow core slab used in validation of the computational model [26] 


\section{Table 4}

Thermal and physical properties ${ }^{\top}$ of concrete and reinforcing steel

\begin{tabular}{ccc}
\hline Property & Concrete & Steel \\
\hline $\begin{array}{c}\text { Thermal conductivity } \\
\left(\mathrm{W} / \mathrm{m} \cdot{ }^{\circ} \mathrm{C}\right)\end{array}$ & 1.33 & 5.33 \\
$\begin{array}{c}\text { Thermal capacitance } \\
\left(\mathrm{W} / \mathrm{kg}^{\circ}{ }^{\circ} \mathrm{C}\right)\end{array}$ & $2.16 \times 10^{6}$ & $3.45 \times 10^{6}$ \\
$\begin{array}{c}\text { Modulus of elasticity } \\
(\mathrm{MPa})\end{array}$ & 43500 & 210000 \\
$\begin{array}{c}\text { Compressive strength } \\
(\mathrm{MPa})\end{array}$ & 75 & - \\
$\quad \begin{array}{c}\text { Tensile strength } \\
(\mathrm{MPa})\end{array}$ & 5.40 & 1900 \\
$\begin{array}{c}\text { Fracture energy } \\
(\mathrm{N} / \mathrm{m})\end{array}$ & 143 & - \\
$\begin{array}{c}\text { Conductivity coefficient } \\
\left(\mathrm{W} / \mathrm{m}^{2}{ }^{\circ} \mathrm{C}\right)\end{array}$ & 25 & - \\
$\quad$ Emissivity & 0.7 & - \\
$\begin{array}{c}{ }^{1} \text { The physical properties of concrete and steel not specified by Shakya and Kodur [26] } \\
\text { were obtained from reference }[36]\end{array}$ & &
\end{tabular}

\subsection{Geometry}

Shakya and Kodur [26] tested and modeled six hollow core slabs subjected to service loading and different fire curves. In this paper, one of the slabs tested by those authors was chosen to validate the computational model. The chosen slab was made with a carbonate coarse aggregate type and was exposed to the standard fire curve defined by ASTM E-119 [2]. The slab had span of $4.0 \mathrm{~m}$, width of $1.20 \mathrm{~m}$, and thickness of $20 \mathrm{~cm}$, with six circular voids and seven prestressing strands of diameter $12.7 \mathrm{~mm}$. Figures 7 and 8 show the cross-section of the hollow core slabs and the mechanical loading scheme, respectively. The hollow core slab was made of concrete with compressive strength of $75 \mathrm{MPa}$, designed according to the PCl Manual [5]. The supports were free for rotation. A mechanical loading of $69.4 \mathrm{KN}$ was applied to the slab, which corresponded to $60 \%$ of the maximum load capacity of the slab in ambient temperature. Shakya and Kodur [26] also developed numerical models in a finite element software to represent the behavior of this hollow core slab when exposed to fire. Further information can be obtained from the reference [26].

\subsection{Material properties}

Table 4 shows the thermal and physical properties of reinforcing steel and concrete used in computational modeling. Shakya and Kodur [26] reported in their work only the physical properties of concrete and steel at ambient temperature, not reporting its strength reduction with temperature. The reduction of the physical properties of concrete and steel with the temperature, used for computational modeling, are shown in Figure 1.

\subsection{Finite element mesh and modeling strategies}

Three different modeling strategies were performed in DIANA ${ }^{\circledR} 9.6$ to determine the temperature profile of the slab cross-section. In
Table 5

Thermal properties of the air

\begin{tabular}{cc}
\hline $\begin{array}{c}\text { Thermal conductivity } \\
\left(\mathrm{W} / \mathrm{m}^{\circ} \mathrm{C}\right)\end{array}$ & $\begin{array}{c}\text { Thermal capacitance } \\
\left(\mathrm{W} / \mathrm{kg}^{\circ} \mathrm{C}\right)\end{array}$ \\
\hline 0.023 & 1210 \\
\hline
\end{tabular}

the first strategy, only the bottom face of the slab was exposed to fire. In the second strategy, the air in the void was included in modeling. In this case, the air in the voids was discretized using the air properties shown in Table 5. Finally, the third strategy considered the heat flow from the lower (hotter) area of the void to the upper (colder) area of the void through convection and radiation flux of the air inside the voids (Figure 9). Figure 10 shows the finite element mesh of the hollow core slab with the discretization of the air in the voids.

The first modeling strategy is typically used in several studies, i.e., the hollow core slab was modeled with voids, but without taking into account the convection and radiation flux inside the voids [35]. The second modeling strategy adopt a solid slab, but in the region of voids the thermal properties of the air were used to simulate the heat flow inside the voids. The accurate modeling of hollow core slabs needs to correctly reproduce the thermal exchange through the concrete and the voids. This modeling strategy is compared with the numerical modeling performed by Shakya and Kodur [26]. This second modeling strategy is similar to that used by other researchers [27].

The third modeling strategy is similar to that performed by Shakya and Kodur [26] and Aguado et al. [20]. In this strategy, there are boundary conditions in the lower (hotter) and upper (colder) areas of the void to provide a heat flow inside the voids. However, the temperatures inside the voids was not determined during the test, so Shakya and Kodur [26] proposed the use of a temperature curve to be applied to the upper area of the voids, which differs

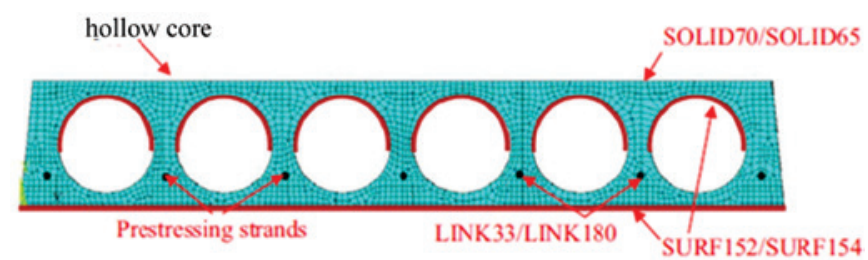

\section{Figure 9}

Finite element mesh with heat flow in voids, from reference [26]

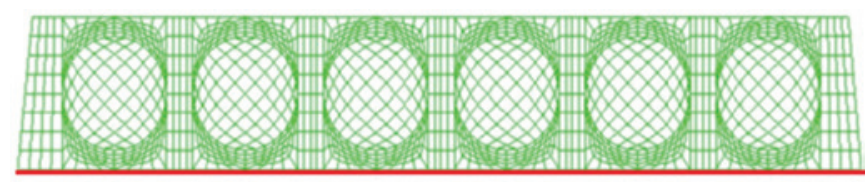

Boundary condition element B2HT

\section{Figure 10}

Mesh of hollow core slab with Q4HT elements with air in the voids included in computational model 


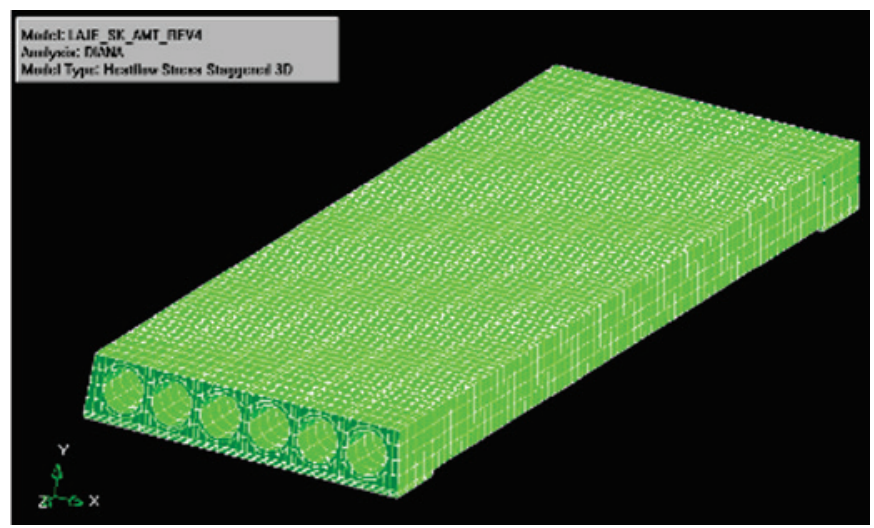

Figure 11

Finite element mesh of the hollow core slab for thermo-mechanical modeling

from the temperature curve on the face exposed to fire. In this paper, this temperature curve was defined from the average of the nodal temperature in lower area of the void. Then, this temperature curve was applied to the upper area of the void to simulate the convection and radiation flux inside the voids. This methodology is similar to that used by Aguado et al. [20].

For the validation of the thermal modeling strategies, a three- dimensional thermo-mechanical modeling was performed (Figure 11). The result was compared with the computational modeling performed by Shakya and Kodur [26] in ANSYS software. The main results analyzed are the vertical displacement of the slab and its cracking pattern.

\subsection{Thermal response}

Temperature profile along the cross-section of the hollow core slab for the three modeling strategies are shown in Figures 12, 13 and 14. For first strategy, with only the bottom face exposed to fire, the maximum temperatures on the bottom face of the slab were $876{ }^{\circ} \mathrm{C}$ and $998^{\circ} \mathrm{C}$ after 60 and 120 minutes, respectively (Figure 12). The temperatures on the prestressing strand were $271^{\circ} \mathrm{C}$ and $504{ }^{\circ} \mathrm{C}$ after 60 and 120 minutes, respectively. Shakya and Kodur [26] obtained in their numerical modeling values of $300^{\circ} \mathrm{C}$ after 60 minutes and $500{ }^{\circ} \mathrm{C}$ after 120 minutes for the temperature of the prestressing strand. The difference between this modeling strategy and the results of Shakya and Kodur [26] is $9.7 \%$ for 60 minutes and $8.4 \%$ for 120 minutes of slab exposure to standard fire. In the top face of the slab, not exposed to fire, the temperature obtained from first modeling strategy was $42{ }^{\circ} \mathrm{C}$, a value $82.7 \%$ lower than that obtained by Shakya and Kodur [26].

For the second strategy, with the air in voids included in the computational model, the temperature profile is shown in Figure 13. The maximum temperatures on the bottom face of the slab after

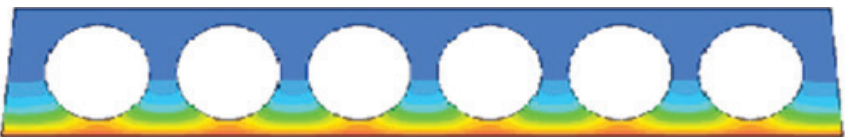

(a)

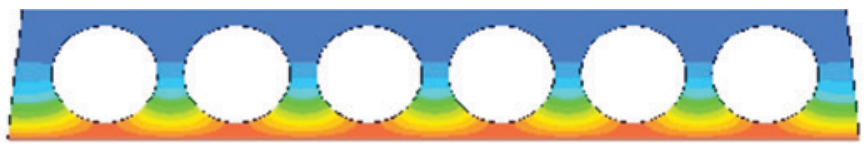

(b)

\section{Figure 12}

Temperature profile in cross-section of hollow core slab - first strategy: a) 60 minutes; b) 120 minutes

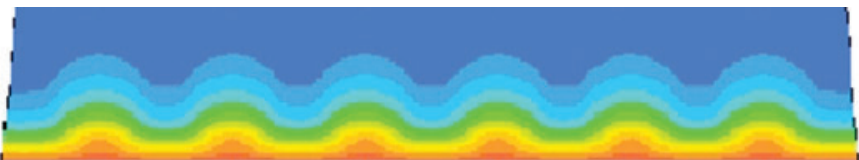

(a)

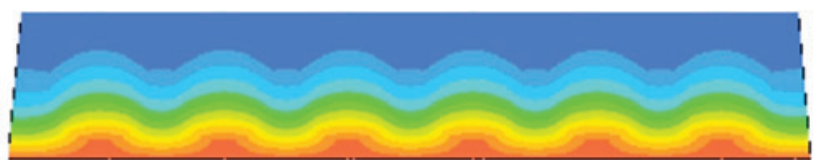

(b)

Figure 13

Temperature profile in cross-section of hollow core slab - second strategy: a) 60 minutes; b) 120 minutes

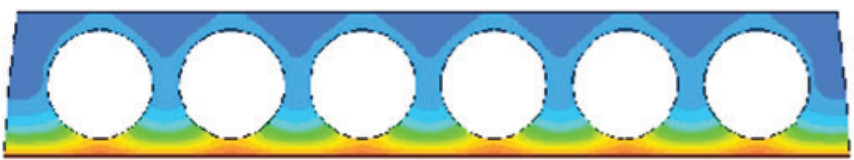

(a)

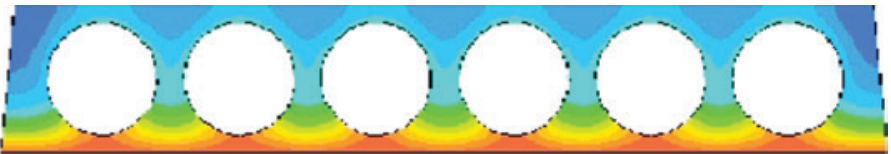

(b)

Figure 14

Temperature profile in cross-section of hollow core slab - third strategy: a) 60 minutes; b) 120 minutes 


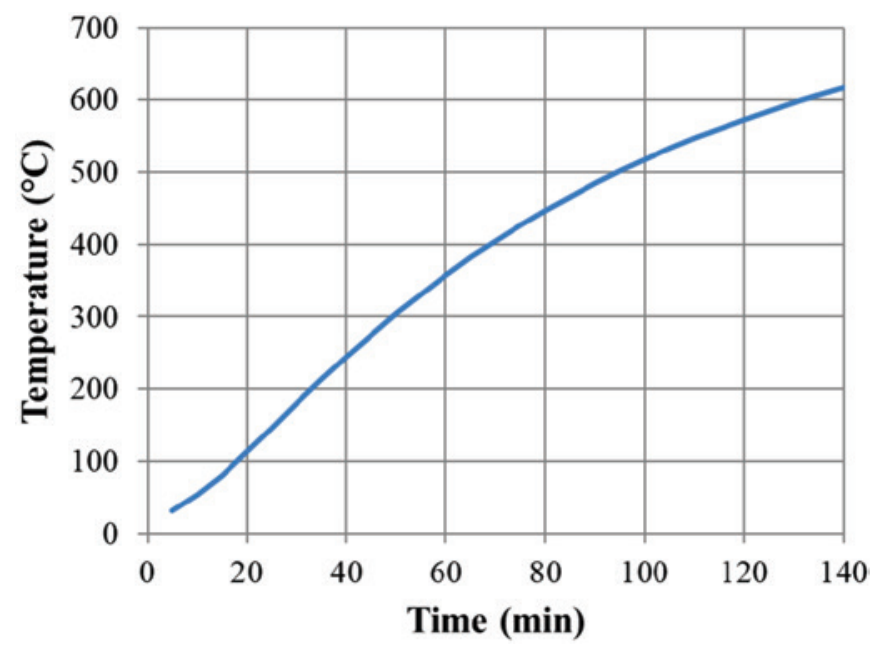

\section{Figure 15}

Temperature-time curve applied to the upper area of voids in hollow core slab with $20 \mathrm{~cm}$ thickness and circular voids

60 and 120 minutes of slab exposure to fire were $908{ }^{\circ} \mathrm{C}$ and $1000{ }^{\circ} \mathrm{C}$, respectively. These values are greater than the temperatures values obtained from the first modeling strategy. The temperature profile showed a wavy shape along the slab, and the maximum temperatures on the prestressing reinforcement were $273^{\circ} \mathrm{C}$ and $494{ }^{\circ} \mathrm{C}$ after 60 and 120 minutes, respectively. The difference between this modeling strategy and the results of Shakya and Kodur [26] was $5.9 \%$ for 60 minutes and $6.2 \%$ for 120 minutes of slab exposure to standard fire. This shows that the heat flow inside the void in fact influences the temperature profile, which implies more elevated temperatures in some regions of the cross-section.

The temperature profile along the cross-section of the hollow core slab for the third modeling strategy is shown in Figure 14. Figure 15 shows the temperature-time curve applied to the upper area of the void to represent the heat flow in the voids. The maximum temperature on the bottom face of the slab was the same as that obtained from the first modeling strategy. However, on prestressing reinforcements the temperature increased to $281{ }^{\circ} \mathrm{C}$ after 60 minutes and to $553^{\circ} \mathrm{C}$ after 120 minutes. The difference between this modeling strategy and the results of Shakya and Kodur [26] was only $3.1 \%$ for 60 minutes, but it was $18.9 \%$ greater for 120 minutes of slab exposure to standard fire. Again, this shows that the heat flow inside the void there influences the temperature profile, implying more elevated temperatures on prestressing reinforcements.

For the top face of the slab, the temperatures obtained from the third modeling strategy are closer to the values obtained by Shakya and Kodur [26] in their modeling and test. The maximum temperature obtained from modeling in DIANA ${ }^{\circledR} 9.6$ was $296^{\circ} \mathrm{C}$, a value only $19.5 \%$ greater than the value obtained by Shakya and Kodur [26].

Figure 16 shows the variation of temperature with fire exposure time in some points of the cross-section of the slab for first, second and third modeling strategies. These points were monitored in the test of the slab exposed to standard fire. It is noted that the third modeling strategy best represents the variation of temperature in the inner region of the slab tested by Shakya and Kodur [26]. For example, the temperature on the top face of the slab in first strategy after 140 minutes was only $42{ }^{\circ} \mathrm{C}$, while in tests of Shakya and Kodur [26] the temperature in this face reached $248^{\circ} \mathrm{C}$. In the second modeling strategy, the temperature on the top face of the slab was only $49^{\circ} \mathrm{C}$ too. That is, in both cases there was a difference about $200{ }^{\circ} \mathrm{C}$ for the value obtained in tests by Shakya and Kodur [26].

In the same way, the temperature at the middle point of the crosssection of the hollow core slab in the first strategy was $50 \%$ lower than the value obtained by Shakya and Kodur [26], while the value obtained from the second strategy was $93 \%$ lower. However, the difference between temperature obtained from the third modeling strategy in DIANA ${ }^{\circledR} 9.6$ and the value obtained by Shakya and Kodur [26] was only $7.8 \%$. In this strategy, however, a more elevated temperature of the prestressing reinforcement after 90 minutes of slab exposure to fire was observed when compared to the values obtained from the modeling and tests of Shakya and Kodur [26]. Therefore, third modeling strategy with the temperature curve shown in Figure 15 is more adequate to represent the inner temperature of the cross-section of the hollow core slab, despite the

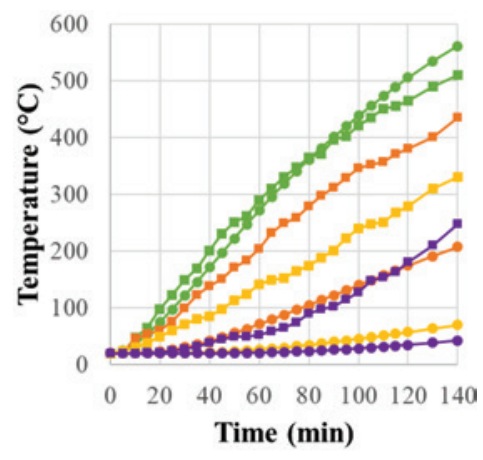

(a)

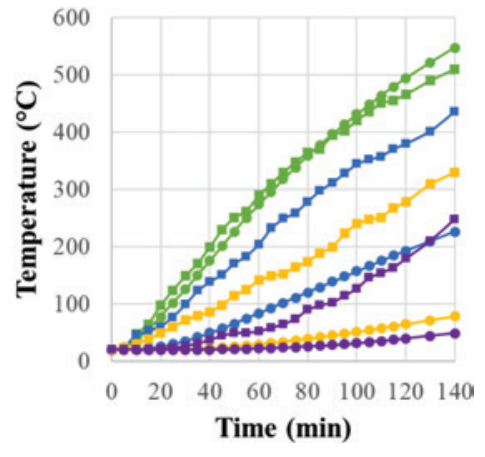

(b)

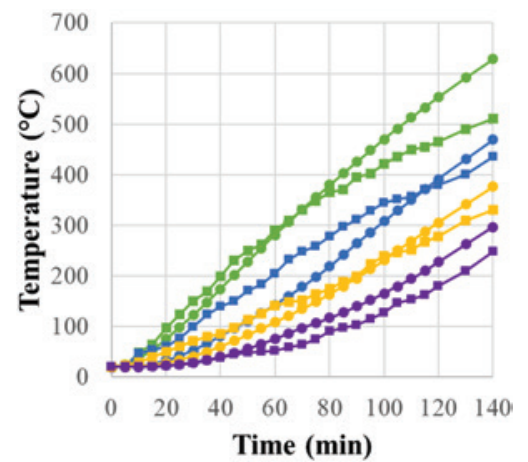

(c)

\section{Figure 16}

Variation of temperature with fire exposure time: a) first strategy; b) second strategy; c) third strategy 
greater temperature observed in the prestressing reinforcements after 90 minutes.

\subsection{Thermo-mechanical response}

The thermo-mechanical model evaluated, besides the temperature profile in the cross-section, the vertical displacement and cracking pattern of the slab when exposed to standard fire. The hollow core slab was simply supported and restricted to displacement in the horizontal (or longitudinal) direction of the slab.

The prestress of strand reinforcement used in modeling was 1305 $\mathrm{MPa}$, which gives a force of $13.18 \mathrm{kN}$ in each strand with diameter of $12.7 \mathrm{~mm}$. This stress represents $70 \%$ of the yield strength of the prestressing steel and was the value applied in the fabrication of

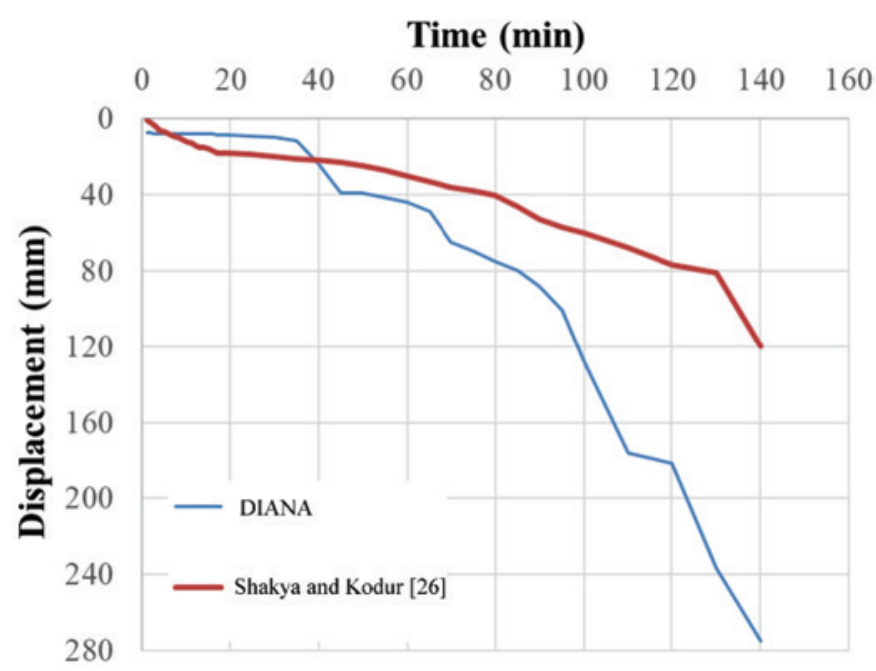

(a)

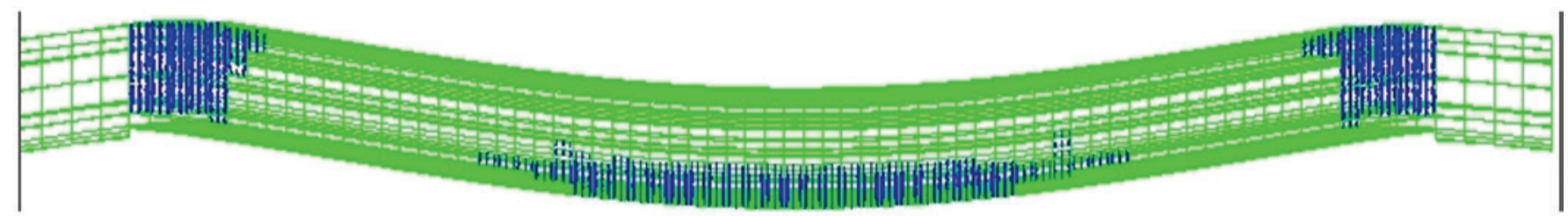

60 minutes

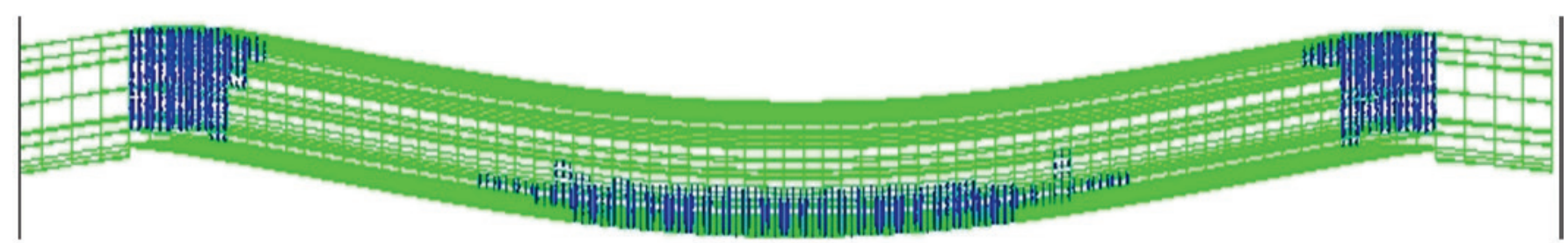

90 minutes

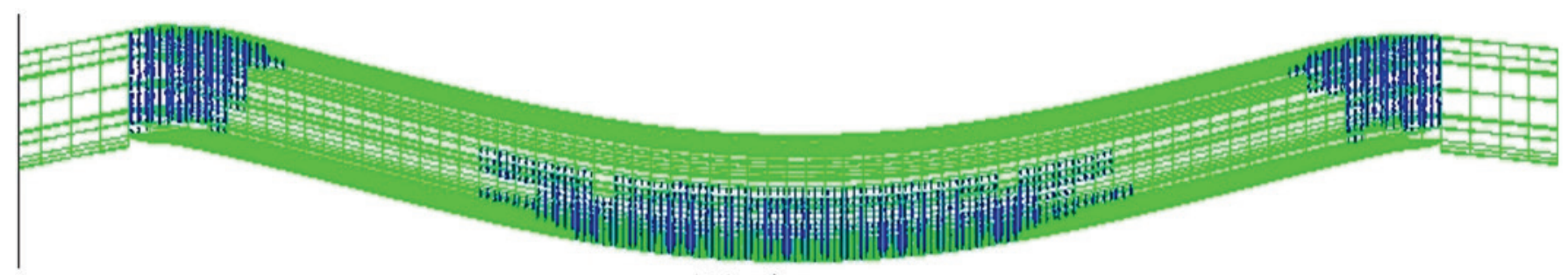

120 minutes

(b)

\section{Figure 17}

(a) Variation of displacement with fire exposure time; (b) cracking pattern of slab after 60,90 and 120 minutes 
the slab [26]. Mechanical loading was represented by means of two concentrated forces of $69.4 \mathrm{kN}$ each, applied according the test setup shown in Figure 8. This loading corresponds to $60 \%$ of the ultimate loading of the slab at ambient temperature.

The variation of the vertical displacement in the middle of the span obtained from thermo-mechanical analysis is shown in Figure 17a. This response is compared to the computational simulation developed by Shakya and Kodur [26], and it is observed that the vertical displacement obtained from DIANA ${ }^{\circledR} 9.6$ software is greater after 40 minutes. This happened even though the temperature in the prestressing reinforcement obtained from the third thermal modeling strategy is the same as the temperature obtained from Shakya and Kodur [26] up to, approximately, 90 minutes. A possible reason for this divergence may be due to the different constitutive laws of concrete used in this paper and that used by Shakya and Kodur [26].

Despite this difference, a small and similar deflection rate up to 90 minutes from the two computational models is observed, i.e., the deflection rate is approximately $0.6 \mathrm{~mm} / \mathrm{min}$ from the modeling of Shakya and Kodur [26] and $0.9 \mathrm{~mm} / \mathrm{min}$ that from the modeling in this paper. The loaded slab was assumed to collapse, according to UNI-EN 1363-1 [27], after 90 minutes when the deflection rate reached the limiting value given as follows:

$\mathrm{v}=\frac{\mathrm{dz}}{\mathrm{dt}}=\frac{\mathrm{L}^{2}}{9000 \mathrm{~d}}(\mathrm{~mm} / \mathrm{min})$

In this expression, $L$ is the span of the slab, and $d$ is the thickness of the slab. For the hollow core slab in this analysis, the limit of the deflection rate is $v=8.9 \mathrm{~mm} / \mathrm{min}$. This value was not achieved in any of the computational models, which indicates that this slab would resist up to 140 minutes of standard fire without reaching collapse. The ultimate bending moment of the hollow core slab after fire exposure using a simplified design method was evaluated in next section to confirm this hypothesis.

Figure $17 \mathrm{~b}$ shows the cracking pattern of the hollow core slab after 60,90 and 120 minutes of fire exposure, obtained from computational modeling. This cracking pattern is very close to that obtained by Kodur and Shakya [26]. The cracks in the longitudinal direction started in the test after 20 minutes, as well as in this computational model. The bending cracks started at 60 minutes, and at 75 minutes the shear cracks appear.

\subsection{Evaluation of flexural resistance by simplified design method}

The flexural resistance of a hollow core slab for a specific time of fire exposure, or residual resistance, can be determined from simplified design methods like the $500{ }^{\circ} \mathrm{C}$ isotherm method described in Section 2.2. If the temperature profile in the cross-section, including the temperature of the prestressing reinforcements, is known, the reduced strength of prestressing steel at elevated temperature is determined from Figure $1 \mathrm{f}$, as recommended by Eurocode 2 [3]. For each time, the flexural resistance is determined from the classical theory of reinforced and prestressed concrete considering the rupture domains for the ultimate limit state defined by Brazilian standard NBR 6118:2014 [37]. The temperature profile used in this analysis was determined from the first and third modeling strategies described in Section 4.4.
Results obtained from simplified design method are compared with the results obtained from computational modeling developed by Shakya and Kodur [26] in Figure 18. It is noted that the ultimate bending moment at ambient temperature for this slab was estimated at $160 \mathrm{kNm}$ by Shakya and Kodur [26] and at $179 \mathrm{kNm}$ by the simplified method. Then, the ultimate bending moment estimated by the simplified design method is only $12 \%$ greater than value obtained from nonlinear mechanical modeling.

The resistance of the prestressing reinforcement decreases with the increase of the temperature, which results in a decrease of the flexural resistance of the hollow core slab. Unitary values for partial factors for the strength of steel and concrete are adopted, and the reduction of the compressive strength of the concrete due to long-term effects (creep) is not considered since a fire is an exceptional action. It is noted from Figure 18 that the rate of decrease of the flexural resistance of the hollow core slab estimated by the simplified design method is slightly greater than that predicted by Shakya and Kodur [26] for up to 80 minutes of standard fire. After this time, the simplified design method with the temperature profile obtained from the first modeling strategy tends to estimate flexural resistance close to values obtained from the nonlinear mechanical modeling, while the third modeling strategy used to determine the temperature profile tends to provide lower flexural resistance.

From Table 3, this hollow core can satisfy a TRRF of 90 to 120 minutes, depending on the ratio between the factored design moment in fire conditions and the design moment capacity at ambient temperature $\left(M_{S d} / M_{R d}\right)$. Since this hollow core slab was loaded by $60 \%$ of its ultimate loading at ambient temperature, the $M_{S d} /$ $M_{R d}$ ratio of this slab is equal to 0.6 , and it can be concluded from Table 3 that this slab would support 90 minutes of standard fire. Taking $M_{S d}=96 \mathrm{kNm}$, i.e., $60 \%$ of the flexural strength at ambient temperature estimated by Shakya and Kodur [26] and $54 \%$ of the flexural strength estimated by the simplified design method, it can be concluded from Figure 18 that the collapse of this slab would be reached between 80 and 90 minutes. This is in agreement with the

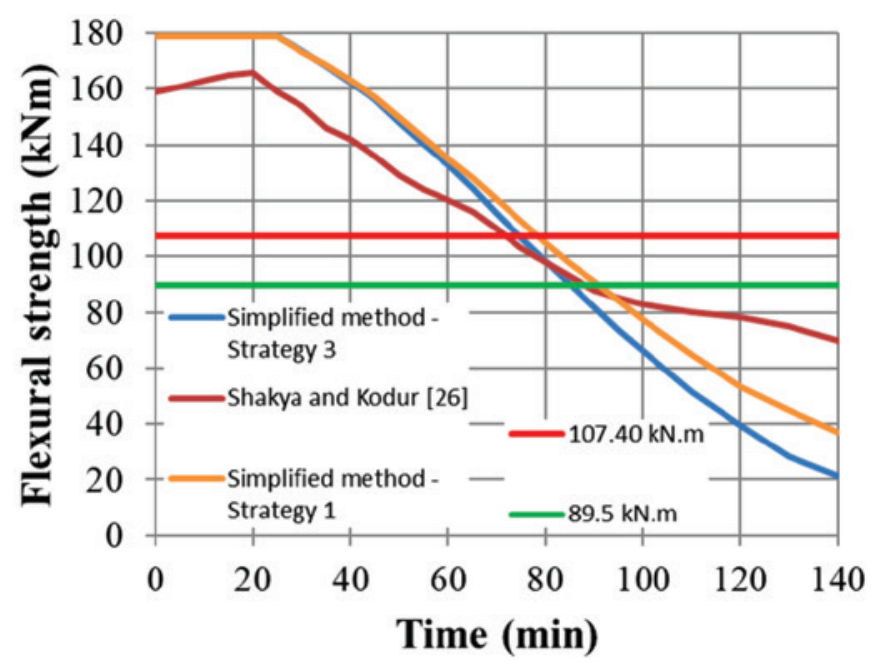

\section{Figure 18}

Flexural strength of hollow core slab with time of exposure to standard fire 


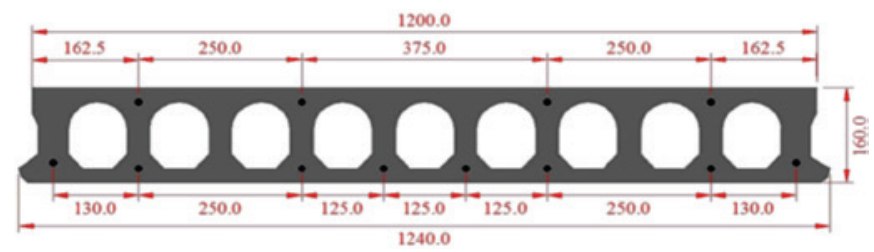

Figure 19

Cross-section of shallow hollow core slab dimensions in $\mathrm{mm}$ [36]

tabulated data presented in Table 3. There is no influence of the thermal modeling strategy in this analysis, since the temperature in the prestressing reinforcement is the same in all strategies until 90 minutes of fire exposure.

If this hollow core slab is required to support 120 minutes of standard fire without collapse, the $\mathrm{M}_{\mathrm{Sd}} / \mathrm{M}_{\mathrm{Rd}}$ ratio from Table 3 should not be greater than 0.49 . That is, the factored design moment in fire conditions of the slab after 120 minutes of exposure to standard fire $\left(M_{S d}\right)$ would be $78 \mathrm{kNm}$. The simplified design method indicates that the slab reaches this flexural strength at 90 to 100 minutes when exposed to standard fire (Figure 18). The greater period of exposure was obtained from the first thermal modeling strategy. This shows that the tabulated data, in this case, overestimate the flexural strength of the slab after 120 minutes of exposure to standard fire.

\section{Shallow hollow core slab exposed to fire}

This section analyzes the performance of a shallow hollow core slab when exposed to standard fire. The hollow core slab taken for this analysis is $16 \mathrm{~cm}$ thick, as commonly used in civil construction with small span or lower live loadings. The geometry of the hollow core slab is shown in Figure 19. The test results of this slab under ambient temperature can be found in reference [36]. For thermal analysis, the bottom face of this hollow core slab was exposed to standard fire recommended by ISO 834 [38]. The temperaturetime curve of ISO 834 is similar to the temperature-curve of ASTM $\mathrm{E}-119$ [2] used in the validation of the computational model.

\subsection{Material properties}

The thermal properties of the reinforcing steel and concrete used in this model are the same as those described in Section 4.2, shown in Table 4, while the physical properties are taken from reference [36]. The prestressing steel is represented by a perfect

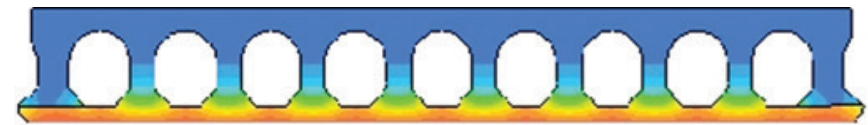

(a)

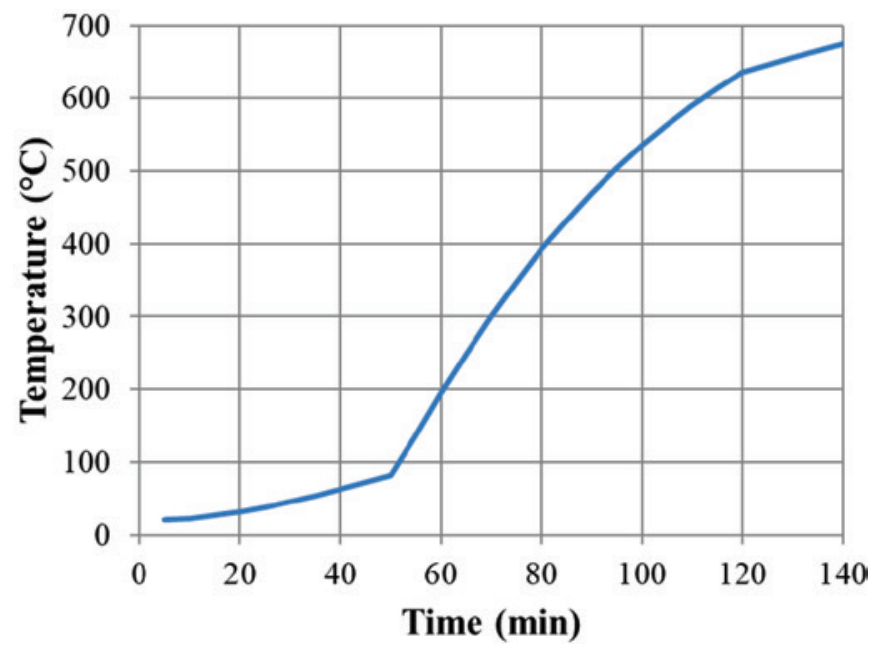

Figure 20

Temperature-time curve applied to the upper area of voids in shallow hollow core slab

elastoplastic material with von Mises yield criterion, both at ambient temperature and at elevated temperature. The yield strength of the steel is $1900 \mathrm{MPa}$. The Total Strain Crack Model with smeared cracking is used to represent concrete behavior. The exponential curve is used in tension softening (Figure 2a), and the parabolic curve is used for compression behavior (Figure 2b). The strength decrease of the material at elevated temperature is similar to that shown in Figure 1.

\subsection{Finite element mesh and modeling strategies}

Two different modeling strategies were performed to determine the temperature profile of the slab cross-section: firstly with the temperature-time curve of ISO 834 applied only on the bottom face of the slab, and secondly considering the heat flow from the lower (hotter) area of the void to the upper (colder) area of the void. The

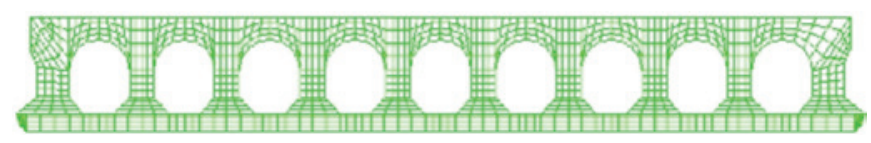

Figure 21

Cross-section of the shallow hollow core slab with finite element mesh

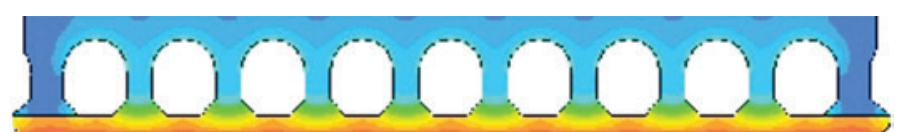

(b)

\section{Figure 22}

Temperature profile after 60 minutes - shallow hollow core slab: a) first modeling strategy; b) second modeling strategy 

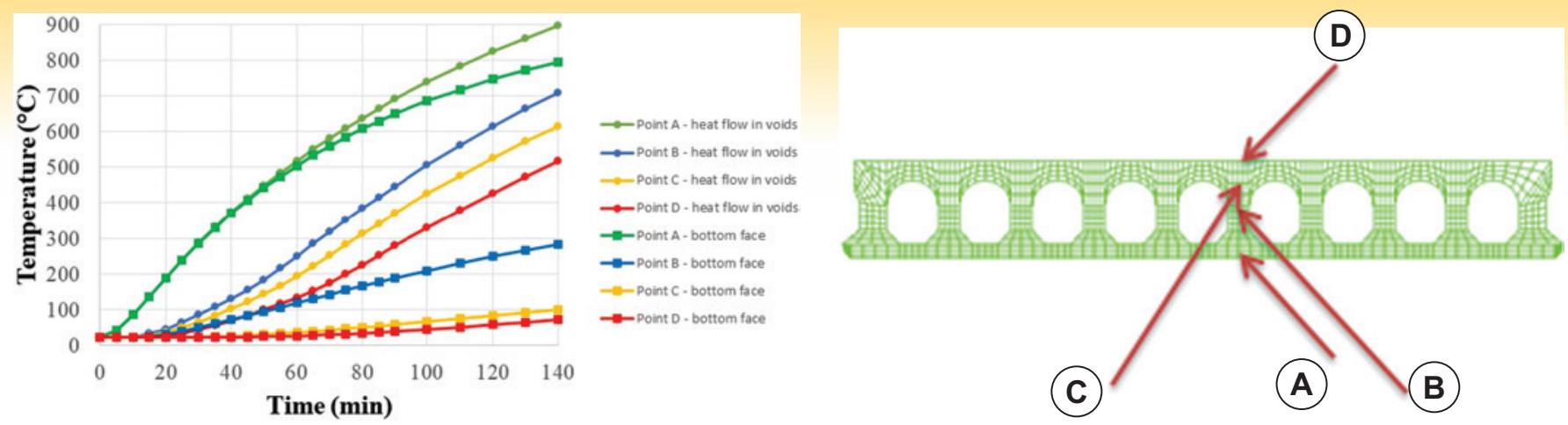

Figure 23

Variation of temperature with fire exposure time - shallow hollow core slab

temperature-time curve to be applied to upper area of the void to simulate the convection and radiation flux inside the voids is defined from the average of the nodal temperature in the lower area of the void. Figure 20 shows the temperature-time curve applied to the upper area of the void for the shallow hollow core slab.

Figure 21 shows the mesh in the cross-section of the slab. The finite elements have an approximate size of $5 \mathrm{~mm}$, resulting in 1266 finite elements. The Q4HT finite element is used in the crosssection of the slab, and the B2HT element is used for boundary conditions. The top face and side faces are insulated and do not transfer heat to ambient air.

\subsection{Thermal response}

The temperature profile along the cross-section of the shallow hollow core slab after 60 minutes is shown in Figure 22. Figure 23 shows the variation of temperature with fire exposure time in the points $A$ (prestressing strand, with a distance of $32 \mathrm{~mm}$ from the bottom face), B (middle thickness of the slab), C (40 mm below the top face) and $D$ (top face). It is noted that the temperature in the prestressing strand for the two modeling strategies is similar until 90 minutes. After this time, it is noted that there is a tendency to more elevated temperatures in modeling strategy with the temperature-time curve applied on upper face of the void. The temperature in points $B, C$ and $D$ in this modeling strategy is much higher, reaching $117{ }^{\circ} \mathrm{C}$ on the top face of the slab after 60 minutes of slab exposure to standard fire. At this time, the temperature in the prestressing strand reaches $505^{\circ} \mathrm{C}$. This value is more than that provided by Figure 24 and by the other technical literature [39], where this value of temperature in the reinforcement was reached only after 120 minutes of slab exposure to fire.
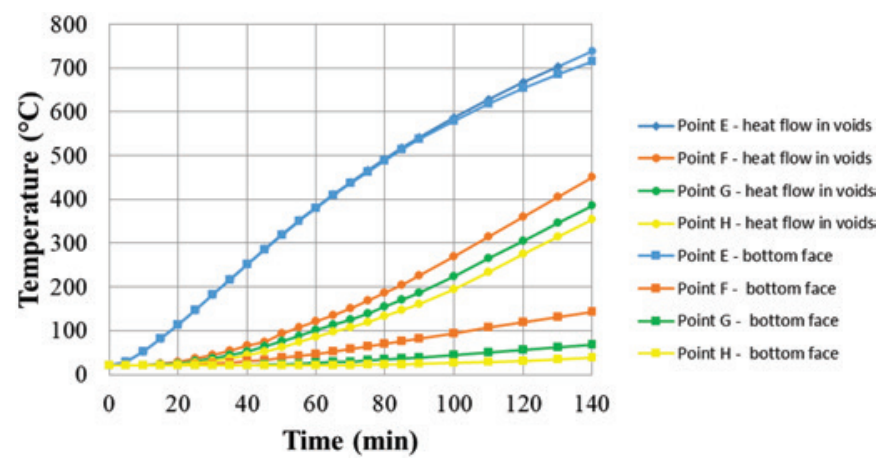

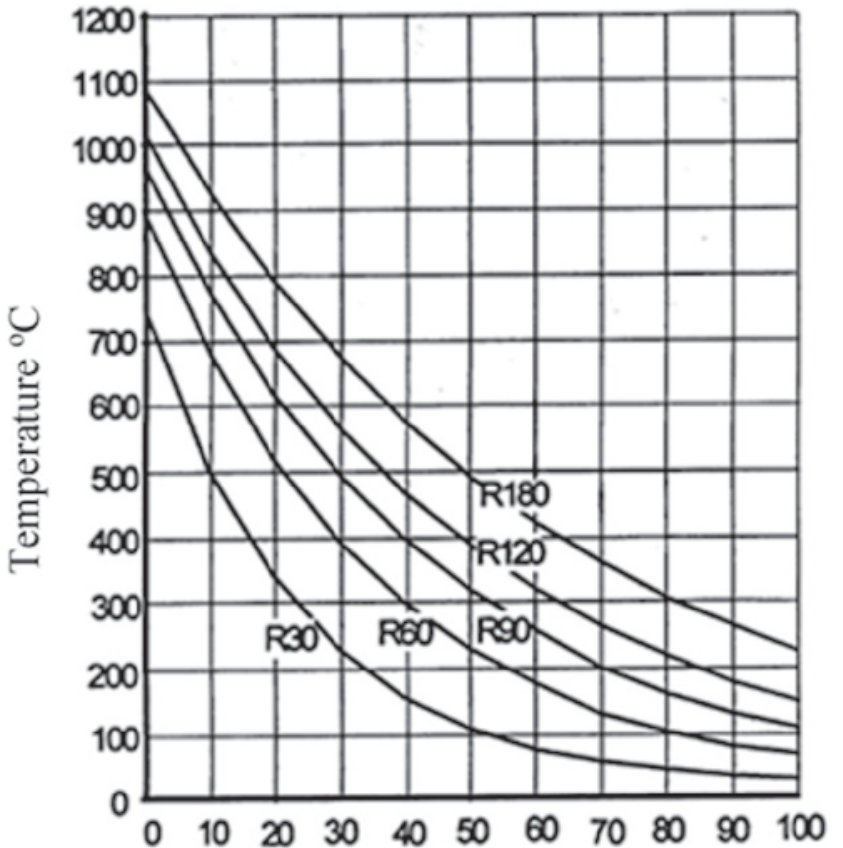

Distance from the face exposed to fire ( $\mathrm{mm})$

\section{Figure 24}

Temperature of reinforcement as a function of the distance from the face exposed to fire [6]

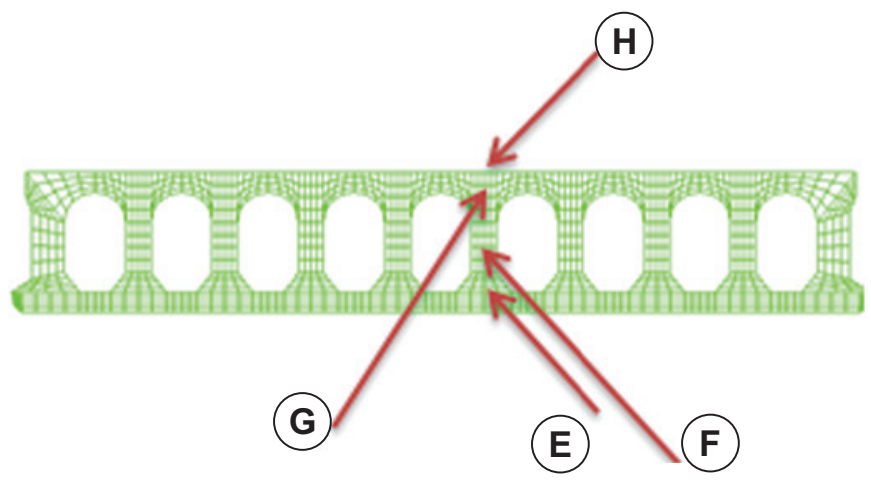

Figure 25

Variation of temperature with fire exposure time - hollow core slab with thickness of $20 \mathrm{~cm}$ 


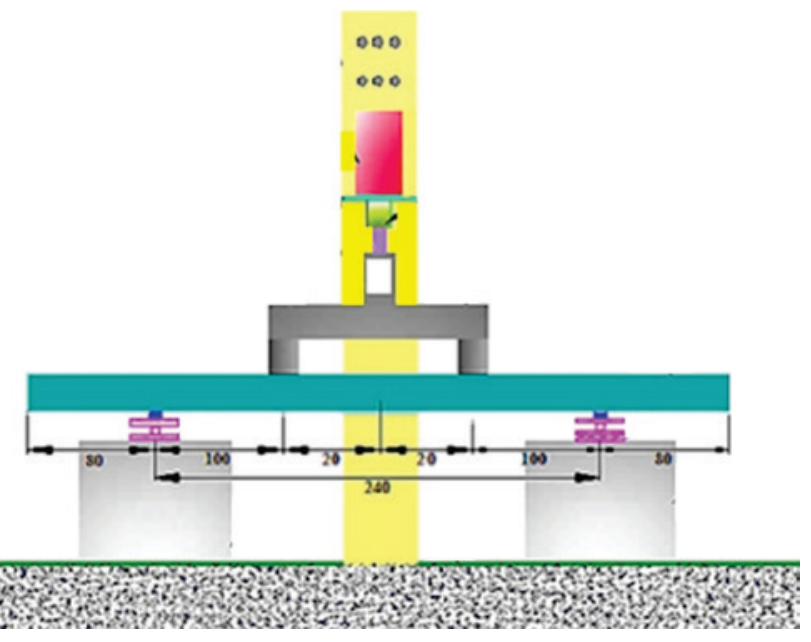

\section{Figure 26}

Test setup for mechanical testing of shallow hollow core slab [36] - dimensions in $\mathrm{cm}$

Mostly, the temperature profile available in the technical literature was obtained from hollow core slabs with thickness greater than $20 \mathrm{~cm}$. When the thickness of this hollow core slab is increased to $20 \mathrm{~cm}$, the temperature in the prestressing strand reaches $380^{\circ} \mathrm{C}$ (Figure 25) after 60 minutes of slab exposure standard fire. This temperature value is similar to that predicted by Figure 24. Then, it can be concluded that besides the distance of the reinforcement to the bottom face of the slab, the thickness of the hollow core has great influence on the variation of reinforcement temperature.

\subsection{Evaluation of flexural resistance}

Initially, the flexural strength at ambient temperature of the shallow hollow core slab was determined from nonlinear mechanical model-

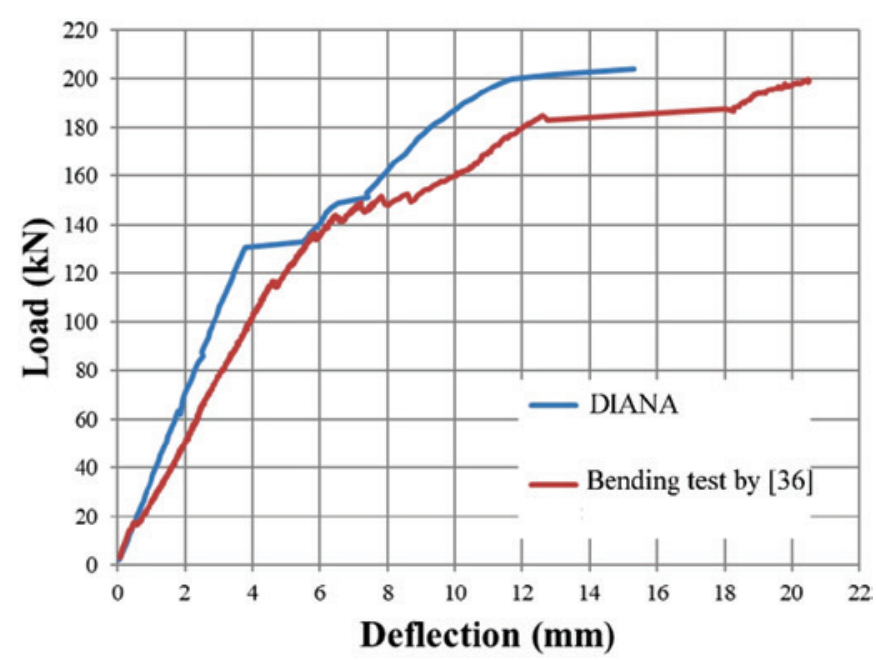

\section{Figure 27}

Load versus deflection for shallow hollow core slab at ambient temperature [36] ing, according to the test setup shown in Figure 26. The bending moment versus deflection of the slab is shown in Figure 27. It is observed that the ultimate bending moment obtained from modeling is $102 \mathrm{kNm}$, while the ultimate bending moment from the test is 99.6 $\mathrm{kNm}$ [36]. A difference of only $2.4 \%$ was observed, which validates the computational modeling. The ultimate bending moment at ambient temperature estimated by the simplified design method is 110.1 $\mathrm{kNm}$, that is, a difference of $10 \%$ from the test value was obtained. This proves the ability of the simplified design method to estimate the flexural strength of the shallow hollow core slab in analysis.

Figure 28 shows the decrease in the flexural resistance of the slab with the time of exposure to standard fire obtained from the $500^{\circ} \mathrm{C}$ isotherm simplified design method, as described in Section 2.2. In this analysis, the first thermal modeling strategy was used, since no influence of the modeling strategy at a temperature of reinforcement until 90 minutes was observed. In this figure, the bending moment of $66.1 \mathrm{kNm}$ is also highlighted, which represents $60 \%$ of the ultimate bending moment at ambient temperature.

According to Table 3, this shallow hollow core slab can satisfy a TRRF of 60 minutes for an $M_{S d} / M_{R d}$ ratio greater than 0.6. However, as can be seen in Figure 28, this $M_{S d} / M_{R d}$ ratio is achieved after 35 minutes of slab exposure to standard fire. After 60 minutes of exposure to standard fire, the flexural strength of the slab is only $29 \%$ of the ultimate bending moment at ambient temperature. This result shows that the tabulated data, in this case, greatly overestimate the flexural strength of the slab after 60 minutes of exposure to standard fire.

\section{Conclusions}

The main conclusions of this research are:

- From the three thermal modeling strategies analyzed, it was concluded that the best representation of the temperature in the cross-section of the hollow core slab with thickness of $20 \mathrm{~cm}$ is given when the temperature-time curve is applied to the upper area of the void to simulate the heat flow into the voids. However,

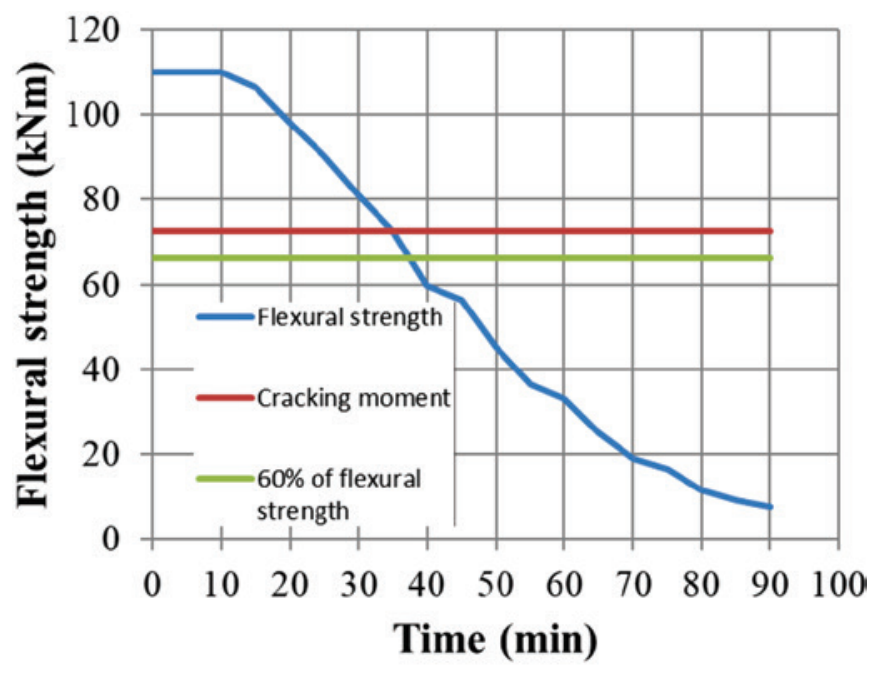

Figure 28

Flexural strength of shallow hollow core slab with time of exposure to standard fire 
this strategy can overestimate the temperature in the reinforcements for exposure to standard fire greater than 90 minutes.

- In the absence of a more precise criterion for estimating the temperature-time curve to be applied for voids, the methodology based an average temperature measured in the lower area of the voids can be used to estimate the temperature in concrete. Similar methodologies are recommended in other research available in the literature, but these studies do not show the temperature-time curve used in computational modeling of hollow core slabs for comparison with the curves obtained in this paper. The analysis of temperature-time curves obtained in this paper for voids shows a clear delay in heat flow of the shallow slab with thickness of $16 \mathrm{~cm}$ with oblong voids when compared to the hollow core slab with circular voids and thickness of $20 \mathrm{~cm}$. However, this delay did not reduce the final temperature in the upper area of the voids after 140 minutes of exposure to fire. This delay is due to the greater distance between the lower face of the voids and the bottom face of the slab in shallow hollow core slabs. This distance is $35 \mathrm{~mm}$ in the shallow hollow core slab and $25 \mathrm{~mm}$ in the hollow core slab with circular voids.

- According to the tabular method presented by Brazilian standard NBR 9062, the $20 \mathrm{~cm}$ thick hollow core slab (with $\mathrm{c}_{1}=44 \mathrm{~mm}$ ) should be able to resist 90 minutes of standard fire when the $M_{S d} / M_{R d}$ is equal to or greater than 0.6 and 120 minutes when this ratio ranges from 0.4 to 0.49 . From the $500^{\circ} \mathrm{C}$ isotherm simplified design method, it is concluded that this slab resists standard fire without collapse until 80 to 90 minutes for $M_{S d} / M_{R d}$ ratio equal to 0.6 and until 90 to 100 minutes for $M_{S d} / M_{R d}$ ratio equal to 0.49 . Thus, the tabulated data are suitable for estimating the fire resistance of the hollow core slab for $M_{S d} / M_{R d}$ ratio equal to 0.6 , but the tabulated overestimate it for $\mathrm{M}_{\mathrm{Sd}} / \mathrm{M}_{\mathrm{Rd}}$ ratio equal to 0.49 .

- The thermal modeling of the shallow hollow core slab with thickness of $16 \mathrm{~cm}$ and $\mathrm{c}_{1}=32 \mathrm{~mm}$ showed that the temperature of the prestressing reinforcement is greater than the values predicted in the technical literature, regardless of the thermal strategy adopted. For 60 minutes of exposure to standard fire, a temperature of the reinforcement was reached that would be reached only at 120 minutes according to the technical literature. This behavior is due to the lower thickness of the hollow core slab, since the same slab, but with thickness of $20 \mathrm{~cm}$, has a lower temperature of the reinforcement, similar to the values predicted in the literature.

- According to the tabulated data of Brazilian standard NBR 9062, a shallow hollow core slab with thickness of $16 \mathrm{~cm}$ and $\mathrm{C}_{1}=32 \mathrm{~mm}$ should be able to resist 60 minutes of standard fire with $\mathrm{M}_{\mathrm{Sd}} / \mathrm{M}_{\mathrm{Rd}}$ ratio greater than 0.6 without collapse. However, from the $500{ }^{\circ} \mathrm{C}$ isotherm simplified design method, the ratio of $\mathrm{M}_{\mathrm{Sd}} / \mathrm{M}_{\mathrm{Rd}}$ equal to 0.6 is reached only after 35 minutes of exposure to standard fire. After 60 minutes of exposure to standard fire, the flexural strength is only $29 \%$ of the ultimate bending moment of the slab at ambient temperature. This result shows that the tabulated data greatly overestimate the fire resistance of the shallow hollow core slab. The temperature profiles available in the literature were generally obtained from hollow core slabs with thickness greater than $20 \mathrm{~cm}$, so they underestimate the temperature profile in shallow hollow core slabs.

Results from this research show the importance of using a more refined method for estimation of the fire resistance of hollow core slabs in projects, since other relevant parameters, such as geometry of the voids, thickness of the slab and the distance from voids to the bottom face of the slab, not only the distance from the reinforcement to the slab face exposed to fire, influence the temperature of the reinforcement. The $500{ }^{\circ} \mathrm{C}$ isotherm simplified design method associated with a temperature profile obtained from a thermal modeling provides more realistic estimates of fire resistance and should, whenever possible, be adopted for the design of hollow core slabs exposed to fire.

\section{Acknowledgment}

The authors wish to thank the Brazilian National Council of Research and Development (CNPq) for financing this research (Project number 442716/2014-1). They also wish to thank the FAPEG (Foundation for research support of the state of Goiás) for granting a scholarship.

\section{References}

[1] EUROPEAN COMMITEE FOR STANDARDIZATION. EUrocode 1 - Actions on structures - Part 1-2: General actions - Actions on structures exposed to fire. 2002.

[2] ASTM International. ASTM E119-15 - Standard test methods for fire tests of building construction and materials. U.S.A, 2015.

[3] EUROPEAN COMMITTEE FOR STANDARDZATION. Eurocode 2 - Design of concrete structures - Part 1-2: General rules - Structural fire design, 2004.

[4] AMERICAN CONCRETE INSTITUTE. ACI 216.1M-07 - Code requirements for determining fire resistance of concrete masonry construction assemblies (metric). U.S.A, 2007.

[5] PRECAST/PRESTRESSED CONCRETE INSTITUTE. $\mathrm{PCl}$ Manual for design of hollowcore slabs. 2. ed. Chicago, 1998.

[6] BRITISH STANDARDS. BS EN 1168:2005. Precast concrete products - Hollow core slabs. 2005.

[7] ASSOCIAÇÃO BRASILEIRA DE NORMAS TÉCNICAS. NBR 15200: Fire design of concrete structures. Rio de Janeiro, 2012 (in Portuguese).

[8] ASSOCIAÇÃO BRASILEIRA DE NORMAS TÉCNICAS. NBR 14432: Fire-resistance requirements for building construction elements - Procedure. Rio de Janeiro, 2001 (in Portuguese).

[9] ASSOCIAÇÃO BRASILEIRA DE NORMAS TÉCNICAS. NBR 9062: Design and execution of precast concrete structures. Rio de Janeiro, 2017 (in Portuguese).

[10] SILVA, V.P. Concrete beams fire design. Enhancement of some recommendations of the Eurocode. Ibracon Structures and Materials Journal, v. 4, n. 2, 277-303, 2011.

[11] SUAZNABAR, J.S., SILVA, V.P. Combined axial and flexural loads in short reinforced concrete columns in fire: ultimate limit state curves using $500^{\circ} \mathrm{C}$ isotherm method. Ibracon Structures and Materials Journal, v. 11, n. 7 , 163-182, 2018. 
[12] CHEREM, M., SILVA, V.P. Determination of the ULS, for columns with small dimensions, under biaxial bending and symmetrical fire conditions. Ibracon Structures and Materials Journal, v. 10, n. 2, 451-476, 2017.

[13] SILVA, V.P. Fire design of reinforced concrete columns. An alternative to the tabular method presented by the Brazilian standard NBR 15200:2004. Ibracon Structures and Materials Journal, v. 1, n. 4, 331-392, 2008.

[14] ROCHA, F. M., MUNAIAR NETO, J. Analysis of slim floor beams in fire: emphasis on the concrete constitutive models. Ibracon Structures and Materials Journal, v. 7, n. 1, 158-177, 2014.

[15] SIMÕES, Y.S., ROCHA, F. M., MUNAIAR NETO, J. Numerical comparison between the thermo-structural behavior of steel and partially encased steel and concrete composite columns in fire. Ibracon Structures and Materials Journal, v. 11, n. 4, 876-901, 2018.

[16] PIERIN, I., SILVA, V.P. Fire design of composite ribbed slabs. Ibracon Structures and Materials Journal, v. 7, n. 2, 178-207, 2014.

[17] RIGOBELLO, R., ALMEIDA, S.J.C., MUNAIAR NETO, J. MALITE, M., SILVA, V.P. The Influence of end conditions on numerical models of cold formed steel and concrete composite beams in fire. Ibracon Structures and Materials Journal, v. 3, n. 3, 357-373, 2010.

[18] HERTZ, K., GIULIANI, L., SøRENSEN, L. S. Fire resistance of extruded hollow-core slabs. Journal of Structural Fire Engineering, v. 8, p. 324-336, 2017.

[19] KAKOGIANNIS, D., PASCUALENA, F., REYMEN, B., PYL, L., NDAMBI, J. M., SEGERS, E., LECOMPTE, D., VANTOMME, J., KRAUTHAMMER, T. Blast performance of reinforced concrete hollow core slabs in combination with fire: Numerical and experimental assessment. Fire Safety Journal, v. 57, p. 69-82, 2013.

[20] AGUADO J. V., ALBERO, V., ESPINOS, A., HOSPITALER, A., ROMERO, M. L. A 3D finite element model for predicting the fire behavior of hollow-core slabs. Engineering Structures, v. 108, p. 12-27, 2016.

[21] AGUADO, J.V., ESPINOS, A, HOSPITALER.A ORTEGA.J, ROMERO.L. Influence of reinforcements arrangement in flexure fire behavior of hollow core slabs. Fire Safety Journal, v. 53, p. 72-84, 2012.

[22] KODUR, V. K. R., SHAKYA, A. M. Factors governing the shear response of prestressed concrete hollowcore slabs under fire conditions. Fire Safety Journal, v. 88, p. 67-88, 2017.

[23] KODUR, V. K. R., SHAKYA, A. M. Modelling the response of precast, prestressed concrete hollow-core slabs exposed to fire. PCI Journal, v. 78, p. 78-94, 2014.

[24] MIN, J., DHAKAL, R. P., MOSS, P. J., BUCHANAN, A. H., $A B U, A$. K. Modelling the fire resistance of prestressed concrete floors using multi-spring connection elements. Journal of Structural Fire Engineering, v. 3, p. 1-18, 2012.

[25] SHAKYA, A. M., KODUR, V. K. R. Modelling shear failure in precast prestressed concrete hollowcore slabs under fire conditions. Journal of Structural Engineering, v. 143(9), 2017.
[26] SHAKYA A.M, KODUR, V.K.R. Response of precast prestressed concrete hollowcore slabs under fire conditions. Engineering Structures, v. 87, p. 126-138, 2015.

[27] VENANZI, I., BRECCOLOTTI, M., D'ALESSANDRO, A., MATEREZZI, A. L. Fire performance assessment of HPLWC hollow core slabs through full-scale furnace testing. Fire Safety Journal, v. 69, p. 12-22, 2014.

[28] COSTA, C.N. Dimensionamento de elementos de concreto armado em situação de incêndio. Tese (Doutorado em Engenharia de Estruturas), Escola Politécnica, Universidade de São Paulo, São Paulo, 2008. doi:10.11606/T.3.2008.tde-04092008-155911.

[29] KLEIN JÚNIOR, O. Pilares de concreto armado em situação de incêndio submetidos à flexão normal composta. Dissertação (Mestrado em Engenharia de Estruturas), Escola Politécnica, Universidade de São Paulo, São Paulo, 2011. doi:10.11606/D.3.2011.tde-17082011-154210.

[30] SILVA, V.P. Projeto de estruturas de concreto em situação conforme a ABNT NBR 15200:2012, São Paulo, Blucher, 1 ed., 2012.

[31] TNO. DIANA: Finite Element Analysis - User's Manual i DIANA. Release 9.6, 1 ed., Netherlands: TNO DIANA, 2015.

[32] ROCHA, F.M. Modelos numéricos de vigas mistas de aço e concreto pertencentes a sistemas de pisos mistos de pequena altura em situação de incêndio. Dissertação (Mestrado em Estruturas), Escola de Engenharia de São Carlos, Universidade de São Paulo, São Carlos, 2012. doi:10.11606/D.18.2012.tde-19032012-090525.

[33] SANTOS, D.B.R. Modelagem numérica de lajes mistas de aço e concreto em situação de incêndio. Dissertação (Mestrado em Estruturas), Escola de Engenharia de São Carlos, Universidade de São Paulo, São Carlos, 2014. doi:10.11606/D.18.2014.tde-04062014-153311.

[34] FEENSTRA, P. H., BORST, R. Aspects of robust computational modelling for plain and reinforced concrete. Heron, , v. 38, n. 4, p. 3-76, 1993.

[35] PIERIN, I., SILVA, V. P. Análise térmica de laje hollow core protendida em situação de incêndio. In: $51^{\circ}$ Congresso Brasileiro do Concreto, 2009, Curitiba. Anais: Concreto para obras de infraestrutura Sustentáveis. São Paulo: IBRACON, 2009. p. 1-17.

[36] SILVA, R.P.M. Resistência à força cortante de lajes alveolares preenchidas de pequena altura, Goiânia, 2015, Dissertação (mestrado) - Escola de Engenharia Civil e Ambiental, Universidade Federal de Goiás, 201p.

[37] ASSOCIAÇÃO BRASILEIRA DE NORMAS TÉCNICAS. NBR 6118: Design of concrete structures - Procedure. Rio de Janeiro, 2014 (in Portuguese).

[38] INTERNATIONAL ORGANIZATION STARDADZATION. ISO 834-1:1999 Fire-resistance tests - Elements of building construction - Part 1: General requirements. Geneva, 1999.

[39] ASSOCIATION OF MANUFACTURERS OF PRESTRESSED HOLLOW CORE FLOORS - ASSAP. The Hollow Core Floor Design and Applications. 1 ed. Verona: Offset Print Veneta. 2002. 